\title{
VIRIBUS UNITIS \\ HRVATSKA POLITIČKA \\ EMIGRACIJA POD \\ KATOLIČKIM \\ SKALPELOM ŽARKA \\ VLAHE
}

Zlatko MATIJEVIĆ

Hrvatski institut za povijest

Ppatička 10

HR - 10000 Zagreb

E-pošta: zlatko.matijevicl@zg.t-com.hr
UDK: 325.25(497.5):929 Vlaho $\check{Z}$

Izvorni znanstveni rad

Primljeno: 2. siječnja 2017.

Prihvaćeno: 5. travnja 2017

"Dilexi iustitiam et odivi iniquitatem, propterea morior in exilio." (Ljubio sam pravdu i mrzio nepravdu, stoga sada umirem u izgnanstvu.)

Papa sv. Grgur VII.

\section{Sažetak}

Žarko Vlaho, jedan od vodećih hrvatskih katoličkih intelektualaca u Hercegovini, našavši se nakon završetka Drugoga svjetskog rata kao emigrant u Argentini, nije pasivno promatrao politička gibanja među Hrvatima u izbjeglištvu. U knjižici Viribus unitis (1950.) oštro se obračunao s pokušajima bivših pripadnika ustaškoga pokreta da ustroje svoje nove stranačke organizacije u inozemstvu. Stavivši pod svoj katolički kirurški nož političko djelovanje Vladka Mačeka, Vlaho se zauzeo za okupljanje svih hrvatskih emigrantskih snaga oko njega, držeći da je riječ o jedinoj osobi koja svojim autoritetom i međunarodnim ugledom može dovesti do stvaranja samostalne hrvatske države. 
Ključne riječi: Žarko Vlaho; Dominik Mandić; Vladko Maček; Alojzije Stepinac; Viribus unitis; Hrvatska; Katolička crkva; Hrvatski katolički pokret; ustaški pokret; totalitarizam; politička emigracija; političke stranke.

Početkom XX. stoljeća zaslugom je krčkoga biskupa Antuna Mahnića ${ }^{1}$ u Trojednoj kraljevini Hrvatskoj, Slavoniji i Dalmaciji, Bosni i Hercegovini te Istri, zemljama u sastavu Austro-Ugarske Monarhije, utemeljen Hrvatski katolički pokret (HKP). ${ }^{2} \mathrm{Na}$ biskupov je poticaj osnovan i Hrvatski katolički seniorat (1912./1913.), ${ }^{3}$ najvažnija i ujedno najkontroverznija organizacija HKP-a. Dio članova Seniorata poznatih pod imenom "nacijonalci"4 opredijelio se za jugoslavensku ideologiju. ${ }^{5}$

Tijekom Prvoga svjetskog rata, razmjerno svojoj brojčanoj snazi i društvenom utjecaju, seniori-"nacijonalci" aktivno su se uključili u

1 O A. Mahniću/Mahniču vidi: Ignacij Radić, Doktor Antun Mahnić biskup krčki, Naklada "Dobra štampa" Z.S.O.J., Slav. Požega, 1940.; Edo Škulu (ur.), Mahničev simpozij v Rimu, Mohorjeva družba v Celju, Celje, 1990.; Anton Bozanić, Biskup Mahnić, pastir i javni djelatnik u Hrvata, Kršćanska sadašnjost, Zagreb - Krk, 1991.

2 Vidi: Jure Krišto, Prešućena povijest - Katolička crkva u hrvatskoj politici 1850.-1918., Hrvatska sveučilišna naklada, Zagreb, 1994.; JuRE KRIŠTO, Hrvatski katolički pokret (1903.-1945.), Glas koncila - Hrvatski institut za povijest, Zagreb, 2004.; Zlatкo Matijević (ur.), Hrvatski katolički pokret. Zbornik radova s međunarodnoga znanstvenog skupa održanog u Zagrebu i Krku od 29. do 31. ožujka 2001., Kršćanska sadašnjost, Zagreb, 2002.; STIPAN TrogRLić, Katolički pokret u Istri 1895.-1914., Hrvatski studiji Sveučilišta u Zagrebu, Zagreb, 2000.

3 Vidi: Zlatko Matıjević, "Hrvatski katolički seniorat i politika (1912.-1919.)", u: Croatica christiana periodica, 24, Zagreb, 46/2000., str. 121-162.

4 O sadržaju pojma "senior-nacijonalac" vidi: Petar Rogulja, "Pred zoru. (Prilog ideologiji katoličkoga pokreta u Hrvatskoj)", u: Zlatko Matijević (ur.), Lučonoše ili herostrati? - Prilozi poznavanju crkveno-nacionalne povijesti Hrvata početkom XX. stoljeća, Erasmus naklada, Zagreb, 2006., str. 285. Također vidi: J. Krišto, Prešućena povijest, str. 340-344; Zlatko Matijević, Slom politike katoličkog jugoslavenstva - Hrvatska pučka stranka u političkom životu Kraljevine SHS (1919.-1929.), Hrvatski institut za povijest - Dom i svijet, Zagreb, 1998., str. 48-56.

5 Jure Krišto, "Katoličko priklanjanje ideologiji jugoslavenstva", u: Časopis za suvremenu povijest, 24, Zagreb, 2/1992., str. 25-45. 
rušenje Monarhije i stvaranje Kraljevstva Srba, Hrvata i Slovenaca/ Jugoslavije. ${ }^{6}$ Nakon osnutka nove države u Mostaru je, početkom 1919. godine, organiziran okružni seniorski zbor za Hercegovinu, ${ }^{7}$ kojem je na čelu bio fra Dominik Mandić, ${ }^{8}$ senior-"nacijonalac". Žarko Vlaho, ${ }^{9}$ Mandićev prijatelj i suradnik, bio je jedan od najvažnijih članova tamošnjeg Seniorata. Svoje političke ideje seniori su nastojali

6 Vidi: J. Krišto, Prešućena povijest, str. 331-366; Z. Matıjević, Slom politike katoličkog jugoslavenstva, str. 37-75.

7 Predsjednik, "Sarajevo", u: Seniorski vjesnik, 3, Zagreb, 2/1919., str. 29.

8 Vidi: Robert Jolić (prir.), Dr. fra Dominik Mandić (1889.-1973.). Zbornik radova sa znanstvenog simpozija održanog u prigodi 40. obljetnice njegove smrti (Mostar - Široki Brijeg, 24. i 25. listopada 2013.), Hercegovačka franjevačka provincija Uznesenja BDM - Franjevačka knjižnica Mostar - Hrvatski institut za povijest, Mostar - Zagreb, 2014.

9 Ž. Vlaho (Mostar, 11. svibnja 1895. - Buenos Aires, 1. siječnja 1960.) završio je osnovnu školu i položio ispit zrelosti na Velikoj gimnaziji u rodnom gradu (1913.). Na Filozofskom fakultetu bečkog Sveučilišta studirao je od 1913. do 1915. godine. Studij je nastavio na Filozofskom fakultetu zagrebačkoga Sveučilišta, ali ga nije završio. Tijekom studija u Beču i Zagrebu bio je član hrvatskih katoličkih akademskih društava Hrvatska i Domagoj. Diplomirao je na Pravnom fakultetu u Zagrebu. Za vrijeme Prvoga svjetskog rata služio je u austro-ugarskoj vojsci (1915.-1918.). Iz rata je izašao s činom pričuvnog natporučnika. Između dvaju svjetskih ratova učiteljevao je u raznim mjestima te radio u gospodarskim i novčarskim institucijama (zadruge i štedionice). Tijekom službovanja u Livnu sklopio je brak s Milkom r. Tadić (1926.). U mjesnoj ih je crkvi vjenčao fra D. Mandić. Jedan od vjenčanih kumova bio je i tadašnji predsjednik HPS-a Stjepan Barić (1889.-1945.), budući ministar socijalne politike u vladi vlč. Antona Korošca (1872.-1940.). U braku se rodilo troje djece: Domagoj, Višnja i Tvrtko. Surađivao je u "Mjesečniku Pravničkog društva u Zagrebu" i zagrebačkom dnevniku "Hrvatsko gospodarstvo". Nakon završetka Drugoga svjetskog rata s obitelji je živio u Argentini. Angažirao se u akcijama za pomoć hrvatskim izbjeglicama i Hrvatima u domovini, osobito Hercegovini ("Društvo hrvatske uzajamne pomoći"). Vlaho je pokopan na buenosaireškom groblju "Flores". Na internetskim se stranicama pojavljuje njegovo ime kao osobe za koju je bivša jugoslavenska država tražila od argentinskih vlasti izručenje zbog navodnoga počinjenja ratnih zločina. Ivo Lendić, "Prof. Žarko Vlaho", u: Hrvatska revija, 10, Buenos Aires, 2-3 (38-39)/1960., str. 274-276; T.(omislav) M.(Esić), "Smrt Žarka Vlahe", u: Danica, Chicago, 27. siječnja 1960., str. 4; Vladimir LonČArević, "Žarko Vlaho - 'intelektualac, vjernik, Hrvat!'", u: Glas koncila, Zagreb, 26. srpnja 2015., str. 21; HRVATSKI DRŽAVNI ARHIV, fond 213, Računarski dvor Nezavisne Države Hrvatske (dalje: RDNDH), kut. 35, (T-Ž); Marko SjekločA, "Ob obletnici razkosanja Jugoslavije", http://www.markosj.net/razkosanje_Jugoslavije.htm (18. 10. 2016.); UKI GoÑI, "The Odessa List", http://ukigoni.com/ odessa/list.htm (18. 10. 2016.). 
ostvariti preko Hrvatske pučke stranke (HPS). ${ }^{10}$ Kao jedan od stranačkih, ali i seniorskih prvaka Vlaho je uređivao mostarski dvotjednik Narodna sloboda, pučkaško glasilo za Hercegovinu.

U razdoblju višestranačke parlamentarne demokracije, pučkaši su bili najogorčeniji politički i ideološki protivnici Stjepana Radića (1871.-1928.) ${ }^{11}$ i njegove Hrvatske (pučke republikanske) seljačke stranke (HSS). ${ }^{12}$ Uvođenjem šestosiječanjske diktature HPS je, kao uostalom i sve druge političke stranke, bio raspušten (1929.). Nakon ubojstva kralja Aleksandra 1934. u Marseillesu i ponovnoga oživljavanja višestranačja, seniori nisu obnovili HPS. Štoviše, najviđeniji članovi vodstva bivše stranke hrvatskih seniora, Petar $\mathrm{Grgec}^{13} \mathrm{i}$ dr. Janko Šimrak, ${ }^{14}$ kasniji križevački biskup, izjavljivali su da "priznaju političkim vođom hrvatskog naroda dr. Vladimira Mačeka". ${ }^{15}$

Vojno-politički slom Kraljevine Jugoslavije i uspostavu Nezavisne Države Hrvatske (NDH), Vlaho je dočekao u Sarajevu kao pročelnik pravnog odjeljenja i prokurist u Šumsko-industrijskom poduzeću "Šipad". ${ }^{16}$ Početkom rujna 1942., odlukom poglavnika Ante Pavelića ${ }^{17}$ primljen je u državnu službu kao vladin nadsavjetnik Glavnoga

10 Vidi: Z. Matıjević, Slom politike katoličkog jugoslavenstva, str. 77-333; Z. Matijević, Lučonoše ili herostrati?, str. 139-221, 331-399.

11 Vidi: Zlatko Matijević, "Hrvatska pučka stranka i Stjepan Radić (1919.1928.)", u: Radovi Zavoda za hrvatsku povijest, 32-33, Zagreb, 1999.-2000., str. 257-266; Zlatko Matijević, "Politika Hrvatske pučke stranke u vrijeme atentata na hrvatske zastupnike u Narodnoj skupštini Kraljevine SHS (1927.-1928. godine)", u: Časopis za suvremenu povijest, 27, Zagreb, 2/1995., str. 233-245.

12 Vidi: Hrvoje Matković, Povijest Hrvatske seljačke stranke, Naklada Pavičić, Zagreb, 1999.

13 P. Grgec (1890.-1962.), katolički književnik, novinar i političar.

14 J. Šimrak (1883.-1946.), grkokatolički svećenik, sveučilišni profesor, političar i novinar.

15 Ivo Lendić, "Hrvatska katolička akcija prema hrvatskoj kulturi, politici i socijalnim pitanjima", u: Luč, 31, Zagreb, 5-6/1936., str. 7. O V. Mačeku vidi: Ivo Perić, Vladko Maček - Politički portret, Golden marketing - Tehnička knjiga, Zagreb, 2000.

16 HDA, 213, RDNDH, kut. 12, (T-Ž). Također vidi: Žarko Vlaho, "Šumsko industrijsko poduzeće ŠIPAD D. D.", u: Hrvatsko gospodarstvo, Zagreb, 14. rujna 1941., str. 7-8.

17 A. Pavelić (1889.-1959.), odvjetnik i pravaški političar; utemeljitelj ustaškog pokreta. 
tajništva Predsjedništva vlade NDH-a u Zagrebu..$^{18}$ Nekoliko mjeseci kasnije, krajem siječnja 1943., imenovan je vijećnikom Računarskog dvora $^{19}$ te je na toj dužnosti ostao do umirovljenja u rujnu $1944 .{ }^{20}$

Krajem ožujka 1943. Vlaho se u Rimu sastao s fra D. Mandićem, s kojim je bio u stalnoj pisanoj komunikaciji, kako bi navodno poduzeli odgovarajuće korake u interesu opstanka hrvatske države i naroda u kolopletu ratnih događanja. ${ }^{21}$ Nakon sloma NDH-a u svibnju 1945., Vlaho s obitelji nalazi privremeno utočište u Italiji. Zahvaljujući fra D. Mandiću smjestio se u Grottaferatti, nedaleko od Rima, gdje je imao i zaposlenje u konviktu hrvatskih akademskih studentica "Pia opera di S. Francesco".22

18 Prilikom stupanja na dužnost Vlaho je 7. rujna 1942. položio obveznu prisegu vjernosti hrvatskoj državi. Tekst prisege glasi: "Prisežem Bogu Svemogućemu i dajem svoju časnu rieč, da ću Državi Hrvatskoj i Poglavniku kao predstavniku njenog suvereniteta vjeran biti, da ću njene ustavne odredbe i zakone poštivati i njih se držati, da ću interese Države Hrvatske i naroda hrvatskog uvjek pred očima imati i požrtvovno promicati, da ću naloge pretpostavljenih savjesno izvršiti. Tako mi Bog pomogao!" HDA, 213, RDNDH, kut. 12, (T-Ž).

19 Vidi: "Zakonska odredba o Računarskom dvoru", u: Narodne novine, Zagreb, 31. srpnja 1941., str. 2-3.

20 HDA, 213, RDNDH, kut. 12, (T-Ž). Zanimljivo je da je predsjednik vlade NDH-a dr. Nikola Mandić (1869.-1945.), prema tvrdnji T. Mesića (1912.1995.), "vrlo cijenio Žarka Vlahu kao kulturnog i gospodarskog radnika i želio, da mu bude suradnikom". T. M., "Smrt Žarka Vlahe", str. 4. Određenu naklonost predsjednika vlade prema Vlahi treba sagledati i u svjetlu činjenice da je N. Mandić u Hercegovini izabran za zastupnika HPS-a u Ustavotvornoj skupštini Kraljevine SHS (1920.-1923.). Z. Matijević, Slom politike katoličkog jugoslavenstva, str. 156.

21 Vidi: Ivica ŠArAC, "Nezavisna Država Hrvatska i Katolička crkva u korespondenciji fra Dominika Mandića"; Tomislav Jonjıć, "Mandićevo hrvatstvo i jugoslavenstvo", u: Dr. fra Dominik Mandić (1889.-1973.), str. 423; 459-463. Također vidi: Vinko Nikolić, Pred vratima domovine - Susreti s hrvatskom emigracijom 1965. Dojmovi i razgovori, I., Knjižnica Hrvatske revije, Buenos Aires, 1966., str. 216. O Vlahinu boravku u Rimu svjedočanstvo donosi i don Ivan Tomas (1911.-1992.), njegov bivši učenik, koji ga je susreo u društvu fra Vitomira Naletilića (1915.-1979.), tadašnjeg tajnika ekonomata u franjevačkoj kuriji u Rimu i suradnika fra D. Mandića. Vidi: Domagoj Tomas (prir.), Pet redaka - Rimski dnevnik svećenika Ivana Tomasa 1943.-1944., Papinski hrvatski zavod svetog Jeronima u Rimu - Sveučilište Josipa Jurja Strossmayera u Osijeku, Odjel za kulturologiju - Biskupski ordinarijat Mostar, Rim Osijek - Mostar, 2014., str. 106.

22 Konvikt je ujesen 1945. osnovao fra D. Mandić iz sredstava franjevačkoga reda. Vidi: JAdRAnKa Neralić, "Mandićevo rimsko razdoblje (1939.-1951.), 
U prosincu 1946. Vlaho se sa suprugom i djecom uputio u Genovu odakle su brodom "Andrea Gritti" otputovali u Argentinu. ${ }^{23} \mathrm{U}$ Buenos Aires su stigli 25. siječnja $1947 .{ }^{24} \mathrm{U}$ organizaciji njihova, kao i puta ostalih hrvatskih poslijeratnih izbjeglica, odlučujuću su ulogu imali Bratovština sv. Jeronima u Rimu, ${ }^{25}$ njezin tajnik vlč. Krunoslav Draganović, ${ }^{26}$ fra D. Mandić, ${ }^{27}$ fra Blaž Štefanićc ${ }^{28}$ i Oscar Ivanissevich, ${ }^{29}$ tadašnji argentinski veleposlanik u Washingtonu (1946.-1948.).

osobito njegova nastojanja oko školovanja franjevačkoga pomlatka i hrvatskih studenata (Grottaferrata, Grottammare)", u: Dr. fra Dominik Mandić (1889.-1973.), str. 729-731, 738; V. LonČAREVIĆ, "Žarko Vlaho", str. 21.

23 Milan Bulajić, Ustaški zločini genocida i suđenje Andriji Artukoviću 1986. godine, Izdavačka radna organizacija "Rad", Beograd, 1988., str. 671.

24 "Passenger list of the ship ANDREA GRITTI arriving to Buenos Aires on Jan 25, 1947", http://www.hebrewsurnames.com/ships_ANDREA\%20GRITTI (18. 10. 2016.). Bila je to prva veća skupina hrvatskih izbjeglica koji su se iskrcali na tlu Argentine nakon završetka rata. Marko Sinovčić, Hrvati u Argentini i njihov doprinos hrvatskoj kulturi - Pregled hrvatskog tiska objavljenog u Argentini od godine 1946. do 1990., Vlastita naklada, Buenos Aires, 1991., str. 39.

25 Vidi: ANdrija Lukinović, "Bratovština sv. Jeronima za pomoć hrvatskim izbjeglicama", u: JuRE BogdAN (prir.), Papinski hrvatski zavod svetog Jeronima (1901-2001). Zbornik u prigodi stoljetnice Papinskoga hrvatskog zavoda svetog Jeronima, Papinski hrvatski zavod svetog Jeronima, Rim, 2001., str. 771-841.

26 Vidi: Jure Krišto, "Krunoslav Draganović i spašavanje hrvatskih izbjeglica nakon Drugoga svjetskog rata", u: DARкo TomAšEvić - Miroslav AkMADžA (ur.), Krunoslav Stjepan Draganović - svećenik, povjesničar i rodoljub. Zbornik radova s međunarodnoga znanstvenog simpozija o Krunoslavu Stjepanu Draganoviću povodom 110. obljetnice rođenja i 30. obljetnice smrti održanom na Katoličkom bogoslovnom fakultetu u Sarajevu od 8.-10. 11. 2013. godine, Katolički bogoslovni fakultet - HKD Napredak - Hrvatsko katoličko dobrotvorno društvo - Glas koncila, Sarajevo - Zagreb, 2014., str. 227-256; MiroSlav AkmadžA, Krunoslav Draganović - Iskazi komunističkim istražitelji$m a$, Hrvatski institut za povijest, Podružnica za povijest Slavonije, Srijema i Baranje, Zagreb, 2010.

27 Jure Krišto, "Fra Dominik Mandić i hrvatske izbjeglice 1943.-1953.", u: Dr. fra Dominik Mandić, str. 694-720; Arhiv Hercegovačke franjevačke provincije u Mostaru (dalje: AHFP), Mandićeva ostavština (dalje: MO), kut. 4, sv. 4, mp. 2, f. 335, "Pozajmice hrv. izbjeglicama iz Fonda Herceg. franj. Provincije", 1. Na popisu osoba koje su dobile novčna sredstva za odlazak iz Europe bio je i Ž. Vlaho.

28 B. Štefanić (1907.-1976.) je u četiri memoranduma tražio i dobio od predsjednika Juana Dominga Peróna (1895.-1974.) dopuštenje za masovno useljavanje Hrvata u Argentinu. M. SInovčić, Hrvati u Argentini, str. 22-23.

29 O. Ivanissevich (1895.-1976.), liječnik, diplomat i političar; ministar obrazovanja u vladi J. D. Peróna (1948.-1950.). 
Nakon dolaska u novu sredinu, u kojoj stariji hrvatski useljenički naraštaj nije pokazivao znakove pretjerane dobrodošlice prema novopristiglim izbjeglicama iz stare domovine, ${ }^{30}$ Vlaho se, nakon određenih problema, relativno brzo snašao ${ }^{31}$ te je zaposlenje našao kao šef računovodstva u buenosaireškoj bolnici "Marini". Pred kraj se života zaposlio u privatnoj klinici "Modelo" u Lanúsu, nedaleko od Buenos Airesa. ${ }^{32}$

Iako se držao podalje od hrvatskih političkih organizacija, Vlaho nije bio nezainteresiran za probleme s kojima su se susretali njegovi sunarodnjaci u izbjeglištvu. Žaleći što njegova razmišljanja o političkim odnosima u hrvatskoj emigraciji nisu mogla biti "objelodanjena u kakovom izrazito katoličkom listu", Vlaho je, smogavši potrebna novčana sredstva, sam tiskao omanji rukopis od 32 stranice pod naslovom - Viribus unitis. ${ }^{33}$ Primjerak je brošure poslao fra D. Mandiću, napisavši u posveti da mu je šalje "u znak dubokog poštovanja i odanosti" kao "prednjaku u borbi za zajedničke ideale". ${ }^{34}$ Nažalost, u Mandićevoj ostavštini nije sačuvan nikakav pisani trag na temelju koga bi se moglo zaključiti kakav je dojam ostavila na njega Vlahina brošura. ${ }^{35}$

U predgovoru je Vlaho istaknuo da je rukopis "ležao preko tri četvrti godine gotov" prije nego što ga je, uz neke "minimalne nadopune", koje se nisu odnosile na iznesene zaključke, predao na uvid zainteresiranoj javnosti. ${ }^{36}$ Poticaj za pisanje našao je u svojoj izbje-

30 M. SinovČić, Hrvati u Argentini, str. 48.

31 Vlaho je izvijestio fra D. Mandića o poteškoćama na koje je naišao prilikom dolaska u Argentinu. AHFP, MO, kut. 3, sv. 3, mp. 2, f. 77-78, Ž. Vlaho D. Mandiću; pismo je datirano u Buenos Airesu, 10. ožujka 1947.

32 T. M., "Smrt Žarka Vlahe", str. 4; AHFP, MO, kut. 6, sv. 6, mp. 5, f. 68.

33 Žarко Vlaho, Viribus unitis - Udruženim Snagama k Zajedničkom Cilju, Vlastita naklada, Buenos Aires, 1950. Uz godinu izdanja posebno je istaknuto da je riječ o "Svetoj Godini", tj. godini svečanoga obilježavanja stote obljetnice smrti argentinskoga i peruanskoga nacionalnog heroja Joséa Francisca de San Martína y Matorrasa (1778.-1850.).

34 Brošura se čuva u Franjevačkoj knjižnici u Mostaru.

35 Vidi: Mario JAREB, "Mandićev odnos prema hrvatskoj (i inoj) političkoj emigraciji za vrijeme i nakon Drugoga svjetskog rata", u: Dr. fra Dominik Mandić, str. 567-582.

36 Ž. Vlaho, Viribus unitis, str. 2. Predgovor je datiran na dan sv. Nikole Tavelića/Tavilića (14. studenoga). 
gličkoj sudbini koja ga je podsjećala na onu njegova velikog uzora pape Grgura VII. ${ }^{37}$

Vlaho je brošuru, nimalo slučajno, započeo riječima - "Bog, Narod i Socijalna pravda", ${ }^{38}$ koje su bile geslo domagojskog časopisa Luč (Beč; Zagreb: 1905.-1942.), jedne od najvažnijih i najdugovječnijih periodičkih publikacija poniklih u krilu HKP-a. ${ }^{39}$ Bio je to nedvosmislen znak da je Vlaho ostao vjeran idealima usvojenima u katoličkim organizacijama pokrenutima od biskupa Mahnića. ${ }^{40}$

Budući da je svojedobno i sam bio član političke organizacije koja je svoj program i djelovanje temeljila na kršćanskim načelima (HPS), ${ }^{41}$ Vlaho nije mogao ne primijetiti da se, navodno, već "dulje vremena" u "užem krugu novih hrvatskih doseljenika" u Buenos Airesu razgovaralo o nužnosti osnutka "KATOLIČKE političke stranke" koja bi okupljala Hrvate. ${ }^{42}$ Ponukan tom viješću držao je nužnim izreći mišljenje o političkim prilikama među hrvatskim izbjeglicama.

Vlaho je bio upoznat s činjenicom da su hrvatski politički emigranti, prvenstveno iz ustaških redova, već osnovali ili pokušavali osnovati nove političke stranke. U Njemačkoj je, prema njegovim saznanjima, Janko Tortić ${ }^{43}$ radio na organizaciji političkog pokreta, dok je u Buenos Airesu osnovana Hrvatska državotvorna stranka. ${ }^{44}$

Krajem rujna 1949. Tortić je objavio poveći članak u kome se vrlo kritički osvrnuo na vodstvo HSS-a i njegovo djelovanje neposredno prije raspada Kraljevine Jugoslavije i u izbjeglištvu te ustaški pokret

37 Isto. Nakon niza sukobâ s Henrikom IV. (1056.-1105.), rimsko-njemačkim kraljem i carem Svetoga Rimskog Carstva, Grgur VII. (1073.-1085.) je morao 1084. napustiti Rim te ostatak života provesti kao prognanik u Salernu.

38 Isto, str. 3.

39 Vidi: Vladimir Lončarević, "Svjetlo katoličke obnove. Uz stotu obljetnicu Luči - 'Lista hrvatskog katoličkog đaštva' (1905-2005)", u: Obnovljeni život, 61, Zagreb, 1/2006., str. 59-78.

40 Ž. Vlaho, Viribus unitis, str. 3.

41 Vidi bilj. 10.

42 Ž. Vlaho, Viribus unitis, str. 3.

43 J. Tortić (1902.-1962.), predratni član HSS-a; doglavnik i ministar u vladi NDH-a. Tomislav Mesić, "Smrt Janka Tortića", u: Danica, Chicago, 10. listopada 1962., str. 2. Također vidi: Jere JAREB, "Svjedočanstvo Janka Tortića o Hrvatskoj seljačkoj stranci i o travanjskim događajima 1941.", u: Časopis za suvremenu povijest, 29, Zagreb, 2/1997., str. 325-367.

44 Ž. Vlaho, Viribus unitis, str. 3. 
i rezultate njegove vladavine u NDH-a, osporavajući im pravo da i nadalje zastupaju interese hrvatskoga naroda. ${ }^{45}$ Polazeći od tvrdnje da većina Hrvata koja se nalazila izvan domovine nije bila politički organizirana, pokrenuo je inicijativu za osnivanje organizacije - "ZA SUVERENU DEMOKRATSKU DRŽAVU HRVATSKU", koja je trebala biti "obći hrvatski pokret sloge i rada". "Simbol i uzori" novoga pokreta bili su S. Radić ${ }^{46}$ i Ante Starčević (1823.-1896.). ${ }^{47}$ U konačnici je Tortićeva akcija trebala rezultirati obnovom hrvatske državne samostalnosti. ${ }^{48}$ Pokret nije nikada zaživio i ostao je samo još jedan od neostvarenih planova hrvatske političke emigracije.

Vlaho je Tortićevu akciju vidio isključivo kao neuspjeli pokušaj jedne politički nedostojne osobe, za koju njezini bivši stranački drugovi nisu imali lijepih riječi, da dokaže kako V. Maček "nije i ne može biti vodja hrv. naroda". 9

Došavši u Argentinu A. Pavelić nije prestao s političkim djelovanjem. Krajem 1949., zajedno sa skupinom istomišljenika, osnovao je novu političku organizaciju pod imenom Hrvatska državotvorna stranka (HDS), koja je, lišena izvanjskih ustaških obilježja, definirana kao "stranka hrvatske državne neovisnosti". ${ }^{50}$ Prema tvrdnji osnivača ona je, u skladu s programskim načelima, išla za "jedinstvenim nastupom cieloga hrvatskoga naroda", kako u domovini tako i u inozemstvu. ${ }^{51}$ HDS je, međutim, ubrzo nestao iz emigrantskoga političkog života, a da nikada nije formalno raspušten.

45 Janko Tortić, "Za Suverenu Demokratsku Hrv. Državu", u: Danica, Chicago, 21. rujna 1949., str. 3, 7.

46 Vidi: Branka Boban, Demokratski nacionalizam Stjepana Radića, Zavod za hrvatsku povijest Filozofskog fakulteta Sveučilišta u Zagrebu, Zagreb, 1998.; TIHOMIR CipeK, Ideja hrvatske države u političkoj misli Stjepana Radića, "Alinea", Zagreb, 2001.; Ivo Perić, Stjepan Radić 1871.-1928., Dom i svijet, Zagreb, 2003.

47 Vidi: Kerubin Šegvić, Dr. Ante Starčević - Njegov život i njegova djela, Tiskara Hrvatske stranke prava d.d., Zagreb, 1911.; Josıp HoRvAT, Ante Starčević - Kulturno-povijesna slika, Nakladni zavod Matice hrvatske, Zagreb, 1990.

48 J. Tortić, "Za Suverenu Demokratsku Hrv. Državu", str. 7.

49 Ž. Vlaho, Viribus unitis, str. 24-25.

50 "Program Hrvatske Državotvorne stranke", u: Hrvatska, Buenos Aires, 1. studenoga 1949., str. 1; Hrvatska Državotvorna Stranka, Buenos Aires, 1950. Također vidi: Bogdan Krizman, Pavelić u bjekstvu, Globus, Zagreb, 1986. , str. 231-235.

51 "Hrvatska Državotvorna Stranka", u: Hrvatska, Buenos Aires, 15. listopada 1949., str. 1. 
Za Vlahu osnutak HDS-a nije bio ništa doli samo još "jedna karika u lancu mnogobrojnih očajnih naprezanja stanovite grupice ljudi, da uvjere svoje malobrojne pristaše (...), da će se oni u domovinu vratiti, da PONOVNO preuzmu vlast, što im je svakako jedini cilj u životu". ${ }^{2}$

Držeći da ne bi bilo korisno za "opću narodnu stvar" da se osnivače HDS-a i program njihove stranke izvrgne javnoj kritici, ${ }^{53}$ iako su to, prema njegovu mišljenju, kao pripadnici ustaškoga pokreta i nositelji vlasti u NDH-a, u potpunosti zaslužili, Vlaho se zadovoljio tvrdnjom da je "ustaštvo po svojoj doktrini i po njezinoj primjeni u praksi" dionik totalitarne ideologije ${ }^{54}$ osuđene ex cathedra od poglavara Katoličke crkve. ${ }^{55}$ Pritom je mislio na dvije glasovite okružnice (enciklike) pape Pija XI. (1922.-1939.), objavljene 14. i 19. ožujka 1937., u kojima je osudio nacionalsocijalizam ("Mit brennender Sorge") ${ }^{56}$ i komunizam ("Divini Redemptoris"). ${ }^{57}$

Nastavivši se razračunavati s "ustaškim totalitarizmom", Vlaho je posegnuo za navodom iz Hrvatske, ${ }^{58}$ glasila koje je promicalo program HDS-a, u kome je totalitarizam najoštrije osuđen: "Totalitarizam je po-

\section{2 Ž. Vlaho, Viribus unitis, str. 3-4.}

53 "O programu hrv. državotvorne stranke mislimo da nije potrebno da se govori, prvo, što taj program, osim nekoliko rečenica o slobodi hrv. naroda i suverenosti hrv. države (što u ustima autora tih rečenica zvuči kao ruganje svakoj slobodi) ne kaže ni u kom pogledu ama baš ništa; a drugo, što su osnivači i nosioci te stranke sve od reda lideri bivšeg hrv. totalitarizma, a dosada se nisu nimalo promijenili, te im je jedina želja (iako srećom neispunjiva), da svoj režim opet nametnu hrv. narodu." Isto, str. 17.

54 O totalitarizmu vidi: Hannah Arendt, Izvori totalitarizma, prev. Mirjana Paić-Jurinić, Disput, Zagreb, 2015.

55 Ž. Vlaho, Viribus unitis, str. 17-18.

56 Vidi: "Enciklika pape Pija XI. 'Mit brennender Sorge' o položaju katoličke Crkve u njemačkom Reichu", u: Katolički list, Zagreb, 6. svibnja 1937., str. 221-224; 13. svibnja 1937., str. 233-235; 20. svibnja 1937., str. 245-247; 27. svibnja 1937., str. 257-258.

57 Vidi: "Encikličko pismo pape Pija XI. 'Divini Redemptoris' o bezbožnom komunizmu", u: Katolički list, Zagreb, 1. travnja 1937., str. 161-164; 8. travnja 1937., str. 173-177; 15. travnja 1937., str. 185-186; 22. travnja 1937., str. 197199; 29. travnja 1937., str. 209-212. Svoju osudu ustaške ideologije Vlaho je pojačao poslijeratnim izjavama pape Pija XII. (1939.-1958.) protiv totalitarizma. Vidi: Ž. Vlaho, Viribus unitis, str. 18.

58 Hrvatska je izlazila u razdoblju od 1947. do 1986.; prva su godišta uredili Vinko Nikolić (1912.-1997.) i dr. Frane (Franjo) Nevistić (1913.-1984.). 
litički opasna stvar i onda, kad se on javlja unutar života i samo jedne stranke. Mjesto žive izmjene misli svih elemenata, koji živu u toj stranci, nastupa njihovo ukočenje POD DIKTATOM JEDNE VOLJE i jednog autoriteta. Taj stranački totalitarizam posebno je opasan onda, kad se pokušava nametnuti ga i izvan redova vlastite stranke, CIJELOJ NARODNOJ ZAJEDNICI."59 Iako su se ove tvrdnje odnosile na V. Mačeka i HSS, ${ }^{60}$ Vlaho ih je upotrijebio kako bi pokazao nesklad između ustaške prakse u NDH-a i aktualnoga političkog položaja u izbjeglištvu.

Kao očite primjere "ustaškog totalitarizma" Vlaho je naveo negativan odnos ustaških vlasti prema papi Piju XII. zbog njegova nepriznavanja hrvatske države (NDH); neodobravanje imenovanja Petra Čule (1898.-1985.) za mostarskoga biskupa u travnju 1942. bez znanja i suglasnosti ustaških vlasti; ${ }^{61}$ pljenidbe propovijedi zagrebačko-

59 Ž. Vlaho, Viribus unitis, str. 19-20. Vidi: "Na putu ujedinjenja svih hrvatskih snaga u emigraciji", u: Hrvatska, Buenos Aires, 1. siječnja 1949., str. 1.

60 "Taj absurdni slučaj imamo mi u našoj hrvatskoj emigraciji. Dr. V. Maček, kao šef ostataka vodstva HSS, preko svoje štampe u S. Americi, Kanadi i nekih listića u Europi, poriče svakom drugom pravo govoriti u ime hrvatskog naroda, osim samom sebi i svojim malobrojnim pristašama. (...) Mi smatramo ovaj ekskluzivizam i totalitarnost ostataka seljačke stranke vrlo opasnom stvari u redovima hrvatske emigracije. Najprije za to, jer nitko, pa čak i najvjerniji Mačekovi pristaše, ne znaju, što dr. Maček u ovom času radi za hrvatsku stvar, a zatim, što se tim načinom rada uvodi u život politički opasna praksa, da nitko ne smije prigovarati, kritizirati ni oponirati. Te zle navike dr. Maček može lako prenieti i u eventualnu buduću Državu Hrvatsku, ako se bude za nju borio i ako u toj borbi uspije. Medjutim, njegov su totalitarizam i izključivost u ovom času najopasniji radi toga, što se uporno šire viesti, da on uobće ne traži Države Hrvatske, nego se pokušava nagoditi sa Srbima u okviru jugoslavenske državne misli. To se često opravdava tobožnjom voljom velikih zapadnih demokracija." "Na putu ujedinjenja svih hrvatskih snaga u emigraciji", str. 1.

61 Vidi: Jure KrišTo, Katolička crkva i Nezavisna Država Hrvatska 1941.-1945., I., Hrvatski institut za povijest - Dom i svijet, Zagreb, 1998., str. 100, 102. Na Čulino imenovanje biskupom u ime vlade službeno je prosvjedovao Mirko Puk (1884.-1945.), tadašnji ministar pravosuđa i bogoštovlja. IvAN GABELICA, Blaženi Alojzije Stepinac i hrvatska država, Vlastita naklada, Zagreb, 2007., str. 236-237. 
ga nadbiskupa Alojzija Stepinca (1898.-1960.) ${ }^{62}$ i samoga poglavara Katoličke crkve. ${ }^{63}$ Posebno je mjesto zauzimao novinski napad Julija Makanca (1904.-1945.), ${ }^{64}$ ministra narodne prosvjete, na Stepinčevu propovijed održanu na blagdan Krista Kralja 31. listopada 1943., u kojoj je nadbiskup osudio komunizam, rasizam i strijeljanje talaca u ratu. ${ }^{65}$ Ustaški je režim nadalje bio odgovoran za "svjesno vrijedjanje i omalovažavanje katoličkih osnovnih principa (ustaška zakletva, koncentracioni logori, nečovječni postupak u logorima i ubijanje zatvorenika, rasni zakoni, židovsko pitanje, srpsko pitanje, cigani-ne-

62 Glede pitanja cenzure Stepinčevih govora vidi: J. KRIšTo, Katolička crkva, I., str. 88, 91; I. GABELICA, Blaženi Alojzije Stepinac, str. 228-230. O nadbiskupu Stepincu vidi: Aleksa Benigar, Alojzije Stepinac - Hrvatski kardinal, Zajednica izdanja Ranjeni Labud, Rim, 1974.; Juraj BATELJA, Živjeti iz vjere - Duhovni lik i pastirska skrb kardinala Alojzija Stepinca, Nadbiskupski Duhovni stol u Zagrebu, Zagreb, 1990.; Vinko Nikolić (prir.), Stepinac mu je ime. Zbornik uspomena, svjedočanstava i dokumenata, I.-II., Kršćanska sadašnjost, Zagreb, ${ }^{2} 1991$; Juraj BATElja, Sluga božji Alojzije Stepinac Spomen zbirka iz ostavštine Sluge Božjega Alojzija Stepinca, Nadbiskupski Duhovni Stol, Zagreb, 1995.; ŽELjкo TANıı́́ (ur.), Kardinal Stepinac - Svjedok istine. Zbornik radova s međunarodnoga simpozija, Zagreb, 19. rujna 2008., Glas Koncila, Zagreb, 2009.; NAtašA Bašić - Vladimir Horvat Josip Mrzljak - Jasna Pavelić-JurešKo (ur.), Kardinal Alojzije Stepinac - Svjedok vremena $i$ vizionar za treće tisućljeće (Stepinčev zbornik). Radovi sa znanstvenoga skupa, Lepoglava, 5. prosinca 2008., Glas Koncila, Zagreb, 2009.; Juraj BateljA, Blaženi Alojzije Stepinac - Svjedok Evanđelja ljubavi. Životopis, dokumenti i svjedočanstva - prije, za vrijeme i nakon Drugoga svjetskoga rata, I.-III., Postulatura blaženoga Alojzija Stepinca, Zagreb, 2010.; Juraj Batelja, Rivellijeva zavjera laži - Blaženi Alojzije Stepinac $i$ Srpska pravoslavna Crkva, Postulatura blaženoga Alojzija Stepinca, Zagreb, 2015.; Gordan Akrap, Kardinal Stepinac u dokumentima Gestapoa i OZN$e$, Udruga sv. Juraj - Glas Koncila - Laser plus, Zagreb, 2016. i dr.

63 Ž. Vlaho, Viribus unitis, str. 20. "Ustaše javno demonstriraju protiv crkve zbog papinog nepriznanja Nezavisne Države Hrvatske. Tako ne idu na tjelovske procesije, apstiniraju se od papinih proslava, zabranjuju pisati u novinama o papi i slično." "Izvještaj A. Juretića J. Krnjeviću, 10. VI 1942.", u: LJubo BoBAn (ur.), Hrvatska u arhivima izbjegličke vlade 1941-1945. - Izvještaji informatora o prilikama u Hrvatskoj, Globus, Zagreb, 1985., str. 161.

64 O J. Makancu vidi: EnIs ZeBić, Od liberalnog do totalitarnog - Filozofija politike Julija Makanca, Izdanje Antibarbarus d.o.o., Zagreb, 2013.

65 Ž. Vlaho, Viribus unitis, str. 20. Vidi: J. KRIšTo, Katolička crkva, I., str. 113, 115; I. Gabelica, Blaženi Alojzije Stepinac, str. 215-218; E. Zebić, Od liberalnog do totalitarnog, str. 184-191. Nadbiskupovu propovijed i ministrov članak vidi u: Stepinac mu je ime, I., str. 45-53. 
muslimani, ubijanje taoca, likvidiranje pol. protivnika makar bili i dobri Hrvati, namjera osnutka Hrv. nar. crkve, ${ }^{66}$ itd., itd.)". ${ }^{67}$

Za Vlahu nije bilo dvojbe da se iz sadržaja Stepinčevih propovijedi i njegovih službenih dopisa poglavniku Paveliću i ustaškim vlastima "može i mora jasno zaključiti, da je ustaštvo bilo onaj pravi, od Sv. Oca osudjeni totalitarizam". ${ }^{6}$ Zato što je "osudjivao i suzbijao grijehe ustaškog režima", Pavelić i ustaše, naglašava Vlaho, "nisu trpjeli" nadbiskupa Stepinca. ${ }^{69}$

Vlaho je posebno isticao Stepinčevo stajalište prema onim katoličkim svećenicima u NDH-a koji su bili dio ustaškog režima ("hrv. svećenici ustaše"). ${ }^{70}$ Nadbiskup u propovijedi, održanoj u zagrebačkoj prvostolnici 26. listopada 1941., u kojoj su osuđene "razne bezbožne teorije i ideologije" jer su "svijet zatrovale mržnjom", kaže: "Postoji pogibao za neke, koji se ponose da su katolici, ili jasnije rečeno, koji imaju duhovni poziv, da će podleći kao žrtve strasti i mržnje niječući najveći zakon kršćanstva - zakon ljubavi."71

66 Vlaho ovdje vjerojatno misli na glasine o ponovnom dopuštanju djelovanja Hrvatske starokatoličke crkve koja je bila zabranjena nakon uspostave NDH-a (1941.). "Izvještaj A. Juretića J. Krnjeviću, 10. VI 1942.", u: Hrvatska $u$ arhivima izbjegličke vlade, str. 187; "Francuski konzul u Zagrebu Gueyraud predsjedniku vlade Lavalu", u: Jure KrišTo (ur.), Katolička crkva i Nezavisna Država Hrvatska 1941.-1945. - Dokumenti, II., Hrvatski institut za povijest - Dom i svijet, Zagreb, 1998., str. 193-194. O starokatolicizmu, odnosno "narodnoj crkvi" u Hrvatskoj vidi: Isprave o Hrvatskoj starokatoličkoj crkvi, Biskupska kancelarija Hrvatske starokatoličke crkve, Zagreb, 1940. Također vidi: Starokatolička crkva u Jugoslaviji, Savez starokatoličkih crkava u FNR Jugoslaviji, Beograd, 1960.; Zlatko Matijević, "Geneza starokatolicizma u Hrvatskoj (1917-1924)", u: Naše teme, 33, Zagreb, 9/1989., str. 2346-2447.

67 Ž. VLAHO, Viribus unitis, str. 20.

68 Isto, str. 20-21. Vidi: Vladimir Horvat, "Nadbiskup Alojzije kardinal Stepinac i totalitarni režimi", u: Obnovljeni život, 51, Zagreb, 1-2/1996., str. 149-166.

69 Ž. Vlaho, Viribus unitis, str. 21.

70 Isto, str. 19. O stajalištu katoličke crkvene hijerahije prema svećenicima koji su bili aktivno uključili u ustaški pokret i obnašali razne državne službe vidi: J. KRIšTo, Katolička crkva, I., str. 122-137.

71 Ž. Vlaho, Viribus unitis, str. 19. Ovdje se nije radilo o navođenju nadbiskupovih riječi iz crkveno-pastoralnog časopisa "Katolički list", gdje je propovijed objavljena, nego o Vlahinu prijevodu sa španjolskog jezika. Vidi: FIoRello Cavalli, El proceso de Monseñor Stepinac, Ediciones Acció Católica Española, Madrid, 1947., str. 68. U izvornom obliku Stepinčev navod glasi: "U ovo zadnjih nekoliko decenija uspjele su razne bezbožne teorije i ideo- 
Da bi dodatno osnažio svoje tvrdnje o nepokolebivu držanju zagrebačkoga nadbiskupa prema ustaškom režimu, Vlaho je posegnuo za izjavom člana Francuske akademije Françoisa Charlesa Mauriaca (1885.-1970.), koji je, nakon što su jugoslavenske komunističke vlasti izrekle dugogodišnju zatvorsku kaznu A. Stepincu, zapisao: "Krivo je mišljenje, da je nadb. Stepinac suradjivao sa ustašama i da ih je pomagao. Naprotiv: nije prestajao da im se odupire, da protestira protiv militarizacije hrvatske mladeži i javno, u svojoj katedrali protiv ubijanja taoca i protiv progona židova... Radi njegovih protesta policija je nadzirala njegovu palaču, u kojoj je u raznim prigodama bio i konfiniran. Nije nikako odobravao držanje raznih svećenika, koji su - potječući iz drugih biskupija - suradjivali sa ustašama usprkos zabranama nadbiskupa."72

Znajući da istina, koliko god bila čvrsto utemeljena u povijesnim činjenicama, nema uvijek odlučujući utjecaj na ideološko-politička uvjerenja pojedinaca, Vlaho je rezignirano ustvrdio: "Nažalost, ima znatan broj svećenika i u emigraciji, koji ne samo da su tvrdokorni u svojoj zabludi, nego još i pomažu, upotrebljujući u svakoj zgodi i uzvišenu osobu nadbiskupa Stepinca, da brane totalitarno ustaštvo i u najcrnjim djelima njegove prošlosti." ${ }^{\text {73 }}$

U tom je kontekstu Vlaho preporučio starijem iseljeničkom naraštaju da svakako pročita knjigu isusovca Fiorella Cavallija (1912.-2004.), ${ }^{74}$ koja je bila dostupna i u Argentini, ne samo da bi imali potpunu sliku o montiranom sudskom procesu protiv zagrebačkoga nadbiskupa,

logije tako zatrovati svijet, da je mržnja postala reć bi glavnim pokretalom sviju ljudskih čina. Pogibelj je da i oni, koji se diče katoličkim imenom, da ne rečem čak i duhovnim pozivom, postanu žrtvom strasti i zaborave na zakon, koji je najljepša karakteristika kršćanstva, zakon ljubavi." Vidi: "Isuse, kralju srdaca, smiluj nam se!", u: Katolički list, Zagreb, 30. listopada 1941., str. 502. Cavalli je uz nadbiskupove riječi dodao sljedeći komentar: "Ne može biti jasnije aluzije na ustaše i na svećenike, kojih je istina malo bilo, koji su slijedili ustaštvo na njegovom krivom putu." Nav. prema: Ž. Vlaho, Viribus unitis, str. 19.

72 Vlaho je Mauriacove riječi preuzeo iz buenosaireškog časopisa za kulturu "Lector". Ž. Vlaho, Viribus unitis, str. 19. Duži izvadak iz Mauriacova teksta, izvorno objavljenog u pariškom listu "Le Figaro" (2. studenoga 1946.), vidi u: Stepinac mu je ime, II., str. 449.

73 Ž. Vlaho, Viribus unitis, str. 19.

74 Knjiga je izvorno napisna na talijanskom jeziku: Fiorello CAVALli, Il processo dell'arcivescovo di Zagabria, Edizioni "La Civiltà Cattolica", Rome, 1947. 
nego da bi također dobili informaciju o ljudima koji su se u Buenos Airesu okupljali oko "Hrvatskog domobrana",75 "Hrvatskog doma"76 i "ostalih ustaških društava i glasila, napose oko t. zv. Hrv. Državotv. stranke".77

Potvrdu za svoje tvrdnje Vlaho je tražio i u izjavama bivših pripadnika ustaškog pokreta. Ivo Vučićević je ${ }^{78}$ polemizirajući s Jurjem Krnjevićem ${ }^{79}$ jednim od najistaknutijih predstavnika HSS-a u izbjeglištvu, ustvrdio da "Krnjević vjerojatno ima u mnogočem pravo, kad se obara na nedjela i žalostne dogadjaje u četiri godine opstanka $\mathrm{NDH}-\mathrm{a}$. On joj može prigovarati, da nije bila niti nezavisna, niti država niti Hrvatska, ali ne može poreći činjenicu, da je hrvatski 10. travnja želio da bude i Nezavisna i Država i Hrvatska. (...) Mi se danas potpuno slažemo sa konstatacijom dra Krnjevića (...), da je zapadni svijet stekao loše mišljenje o ustašama i bila bi politička ludost od Hrvata, kad bi htjeli oživjeti ustaštvo kao jedinog spasonosnog nosioca hrvatske državnosti". ${ }^{80}$ Ipak, za Vučićevića je presudan bio odnos vodstva HSS-a prema hrvatskoj državnoj samostalnosti: "hoće li naime Hrvatska seljačka stranka dobrovoljno priznati obnavljanje stare Jugoslavije i hrvatsku državnost 'uokviriti' srpskom dinastijom ili kakvom drugom jugoslavenskom kombinacijom ili će pak ova do sada najveća hrvatska stranka tražiti za hrvatski narod pravo samoodluke o njegovoj sudbini prije nego što Hrvati budu 'uokvireni"'. ${ }^{1}$

75 O nastanku i djelovanju organizacije "Hrvatski domobran" vidi: MARIO JAREB, Ustaško-domobranski pokret - Od nastanka do travnja 1941. godine, Hrvatski institut za povijest - Školska knjiga, Zagreb, 2006. Organizacija je nastavila s djelovanjem i nakon završetka Drugoga svjetskog rata. B. KRIZman, Pavelić u bjekstvu, str. 223-225; Ivan Jelić, Otvorena riječ - Sjećanja i oplakivanja, Vlastita naklada, München, 1987., str. 181; Hrvoje Matković, Povijest Nezavisne Države Hrvatske, Naklada Pavičić, Zagreb, 2002., str. 248.

76 "Hrvatski dom" je osnovan sredinom 1949. M. Sinovčıć, Hrvati u Argentini, str. 60-61. Vidi: "Hrvati Argentine imaju Dom", u: Hrvatska, Buenos Aires, 14. srpnja 1949., str. 1-2.

77 Ž. Vlaho, Viribus unitis, str. 21.

78 I. Vučićević (1920.-2007.), novinar i urednik radijskog programa za Hrvate u iseljeništvu.

79 J. Krnjević (1895.-1988.), političar; glavni tajnik i kasniji predsjednik HSS-a.

80 Ž. Vlaho, Viribus unitis, str. 20-21. Vidi: Ivo VučıćEvić, "Da se razumijemo", u: Danica, Chicago, 15. prosinca 1948., str. 3.

81 I. VučićEvić, "Da se razumijemo", str. 3. 
Dragutin Kamber ${ }^{82}$ katolički svećenik, koji je 1941. obnašao dužnost ustaškog povjerenika za kotar Doboj, u emigraciji je objavio članak koji se dobro uklapao u Vlahinu sliku ustaškoga totalitarnog režima ustrojenog prema fašističkom i nacističkom uzoru: "A koliko se god mi prali, ne možemo uvjeriti ni svoje a kamo li strance, da smo prošli kraj fašizma i nacizma kao nevina janjad. Imitirali smo uniforme, pozdrav, poze i sav vanjski izgled. A podijelili smo i vojsku - ludo - na dvije gotovo neprijateljske skupine kao i u Njemačkoj i u Italiji. ${ }^{83}$ Ustaštvo, mjesto da bude ili narodni pokret ili stranka ili vojska, htjelo je (nespretnošću poglavara), da bude sve i povezalo se je osobno s njime. I u tom pogledu tragično smo imitirali primjer Hitlera i Mussolinija. Pa smo pomalo počeli usvajati ideje o nadčovjeku i podčovjeku i sofistički piskarati, kako se volja i misao jedne nacije znade kondenzirati $u$ jednoj osobi (pa prema tome ta osoba ne treba da sluša ni narod ni pametne ljude, svi trebaju slušati nju), pa smo ponešto tu doktrinu primjenili na primjer na cigane ... Pa ne možemo nijekati da nijesmo slijepo preveli Mussolinijevski pozdrav pronto u spremno, 'Duce ha sempre ragione' u 'Poglavnik ima uvijek pravo'; 'Samo Poglavnik vodi politiku', itd., itd. Kakove je (...) još trebalo prihvatiti fašističko-nacističke elemente, da bi se vidjelo, da smo njihovi sateliti i šegrti?"84 Unatoč oštrim riječima, Kamber se nije odrekao svoje prošlosti, ali se zauzimao za napuštanje ustaškog imena u političkoj borbi: "Ja se osobno ne stidim i ne poričem svoju suradnju sa upravom $\mathrm{NDH}$, sa ustašama; upoznao sam medju njima heroje, najljepše hrvatske karaktere i najidealnije borce i mladiće, kao i opet stanoviti broj najordinarnijih glupana i propalica. To (ustaško) ime treba prepustiti povijesti... Bacimo se radije na obćenarodni posao (...)."85

Za dokazivanje totalitarnoga karaktera ustaškoga režima, Vlahi je poslužio i članak koji je objavljen u povodu obilježavanja sedme obljetnice proglašenja NDH-a. ${ }^{86}$

82 D. Kamber (1901.-1969.), vojni vikar u Bosni i Hercegovini i pročelnik duhovnikâ Hrvatskih oružanih snaga u NDH-a.

83 Kamber aludira na dvojnost njemačke i talijanske oružane sile, tj. podjelu na Wehrmacht i SS, odnosno Esercito i Milicia fascista.

84 Ž. Vlaho, Viribus unitis, str. 21-22. Vidi: "Poučna poruka sveć. Kambera njegovim bivšim prijateljima", u: Hrvatski glas, Winnipeg, 12. listopada 1948., str. 3.

85 "Poučna poruka sveć. Kambera njegovim bivšim prijateljima", str. 3.

86 "Nezavisnoj Državi Hrvatskoj (...) predbacili SU TOTALITARIZAM I KOLJAČTVO. AKO JE TO POGRJEŠKA REŽIMA, ne smije se osuditi državnu 
Nastavivši analizirati "totalitarizam ustaškog pokreta" Vlaho se osvrnuo na poglavlje iz Pavelićevih tada još neobjavljenih uspomena iz vremena prije Drugoga svjetskog rata. ${ }^{87}$ Posprdno nazivajući Pavelića - "povjesničarom", posebno se uhvatio za njegovu tvrdnju da Turci, nakon osvajanja Bosanskoga kraljevstva u XV. stoljeću, u kojem su važnu ulogu imali pripadnici Crkve bosanske ("bogumili"), nisu prisilno islamizirali domaće kršćansko stanovništvo nego da je bila riječ o dragovoljnom činu motiviranom prvenstveno političkim razlozima, tj. "neprijateljstvo prema hrvatsko-ugarskim kraljevima i Rimu", kao središtu zapadnog kršćanstva. Navodno je kod prijelaza "bogumila" na islam imala ulogu i stanovita "bliskost" dviju religija. ${ }^{88}$ O Pavelićevu diletantskom tumačenju prošlosti trebao je posvjedočiti i podatak da mu je povijesna vrela u Vatikanskoj knjižnici 1932. s "neobičnom marljivošću, točnošću i urednošću" prikupljao Marko Fil. Vujeva (1898.-1945.), ${ }^{89}$ osebujna pojava nesvakidašnjega životnog puta i predratni član ustaške organizacije, koji je navodno ubijen u tzv. Luburićevoj vojarni u Zagrebu. ${ }^{90}$

Prikazavši Pavelićevu interpretaciju srednjovjekovne bosanske crkveno-političke povijesti, Vlaho je, ne posve uvjerljivo, ustvrdio da

misao i volju naroda, da bude slobodan u svojoj Državi." Ž. VLAHo, Viribus unitis, str. 21. Navod je sadržajno točan iako je Vlaho ispustio nekoliko riječi, a da to nije posebno označio. Također u izvorniku nema verzalom tiskanih slova. Vidi: "Hrvatska narodna duša", u: Hrvatska, Buenos Aires, 1. svibnja 1948., str. 1.

87 Vidi: Ante Pavelić, "Gjulhisar - jedno poglavlje iz rukopisnog djela 'Doživljaji"', u: Franjo Nevistić - Vinko Nikolić (ur.), Hrvatska - Kulturnopolitički zbornik, Izdala: Hrvatska - glasilo Hrvata Južne Amerike, Buenos Aires, 1950., str. 25-46. Vidi: Ante PAvelić, Doživljaji, I., Naklada Starčević, Zagreb, 1996., str. 83-115.

88 Ž. Vlaho, Viribus unitis, str. 22-23. Vidi: A. Pavelić, "Gjulhisar", str. 32-34.

89 Vidi: Marko Fil. Vujeva, Moj politički životopis, Vlastita naklada, Buenos Aires, 1928.

90 Ž. Vlaho, Viribus unitis, str. 23. Vidi: A. Pavelić, "Gjulhisar", str. 32. Također vidi: Jere Jareb (ur.), Političke uspomene i rad dra Branimira Jelića, Izdavač Mirko Šamija, Cleveland, 1982., str. 42-43; B. Krizman, Pavelić u bjekstvu, str. 325; Eugen Dido Kvaternik, Sjećanja i zapažanja 1925-1945 Prilozi za hrvatsku povijest, Jere Jareb (ur.), Nakladničko društvo Starčević, Zagreb, 1995., str. 329; VjeKoslav VRančić, Branili smo državu - Uspomene, osvrti, doživljaji, I., HB PRESS, Washington, 2006., str. 120-121. Zanimljivo je da se Vujeva ne spominje u konačnoj verziji Pavelićevih uspomena. Usp.: A. Pavelić, "Gjulhisar", str. 32; A. Pavelić, Doživljaji, I., str. 93. 
je time na "najzgodniji" način završio dokazivanje o "totalitarizmu ustaškog pokreta". ${ }^{1}$

Vlahi je bilo "nevjerojatno" da je u novoj generaciji emigranata bilo ljudi, kao onih okupljenih oko HDS-a, koji su držali da će oni biti odlučujući čimbenik u budućoj samostalnoj hrvatskoj državi te da će u njoj provoditi "pravu soc. pravdu i proti nekontroliranom pretjeranom kapitalizmu i proti svakoj staleškoj diktaturi".92 Za njega nije bilo dvojbe da je budućnost Hrvatske u rukama onih koji su ostali u obnovljenoj Jugoslaviji pod komunističkom vlašću. U tom je kontekstu trebalo sagledati i pitanje osnivanja političke stranke u budućnosti, tj. Hrvati u domovini će, prema Vlahinu mišljenju, "kad to ustreba" donijeti o tome "pravu odluku"..$^{3}$ Nije moglo biti jasnije osude pokušaja stranačkog reaktiviranja ostataka bivših pripadnika ustaškoga pokreta iz pera jednoga katoličkog intelektualca.

Kritički osvrt na emigrantska nastojanja oko političkog organiziranja poslužio je Vlahi za postavljanje važnoga pitanja - "da li je HRVATIMA U SADAŠNJIM PRILIKAMA POTREBNA IKAKOVA POLITIČKA STRANKA, NAPOSE, DA LI JE POTREBNA POLITIČKA KATOLIČKA STRANKA".94

Glede potrebe organiziranja "političke katoličke stranke" u emigraciji, Vlaho je držao da ima "legitimaciju" da o tome iznese gledište jer je "čitav život" bio angažirani katolički javni djelatnik. ${ }^{95}$

Da bi dao konačan odgovor na gornje pitanje, Vlaho je ponovo, možda ne sasvim slučajno, posegnuo za citatom iz Pavelićeve Hrvatske: "Sadašnja hrvatska narodna borba imajući pred očima kao jedini cilj odstranjenje boljševičkog režima sa hrv. drž. područja i uspostavu demokratske narodne vladavine, jest obćenarodna, te nema i ne smije imati stranačko-političko obilježje, niti sadržaja. Svako strančarenje u sadašnje doba jest štetno." ${ }^{96}$

Za Vlahu je takvo stajalište bilo "JEDINO ISPRAVNO", čak i onda kada je dolazilo iz redova onih s kojima se najoštrije razračunavao na

91 Ž. Vlaho, Viribus unitis, str. 23.

92 Isto, str. 3. Vidi: "Hrvatska Državotvorna Stranka", str. 1.

93 Ž. Vlaho, Viribus unitis, str. 4.

94 Isto, str. 3.

95 Isto.

96 Isto, str. 5. Navod je u izvorniku pisan verzalom. Vidi: "Hrvatska 'Treća snaga'", u: Hrvatska, Buenos Aires, 1. lipnja 1948., str. 3. 
stranicama svoje brošure. Ako se pred očima imalo rušenje komunističkoga sustava i uspostavu demokratske hrvatske države, iz toga je mogao slijediti samo jedan logičan zaključak - Hrvatima, u međunarodnim političkim okolnostima nastalima nakon Drugoga svjetskog rata, nisu "potrebne nikakove političke stranke". ${ }^{97}$ Dosljedno tome, politička stranka s katoličkim predznakom također nije bila potrebna. Tek nakon državnoga osamostaljenja Hrvatske stvorile bi se pretpostavke za organiziranje višestranačkoga političkog života.

Dajući prednost hrvatskom narodu u domovini nad njegovim iseljenim dijelom, Vlaho nije namjeravao podcijeniti iseljeništvo. Izričito je tvrdio da je ono kao "dio narodnog organizma" u "prošlosti" bilo "prvoborac" za hrvatsku narodnu slobodu. Prema njegovu mišljenju "veći dio zasluga za pobjede hrv. narodne stvari izvojevane u prošlosti pripada baš zasluzi hrvatskih iseljenika". ${ }^{98}$ Vlahina se pohvala odnosila na djelovanje hrvatskoga iseljeništva u Južnoj Americi tijekom Prvoga svjetskog rata te rušenja Austro-Ugarske Monarhije i stvaranja prve jugoslavenske države. ${ }^{99}$

Uzimajući u obzir činjenicu malobrojnosti hrvatskoga naroda s jedne strane te velike ljudske gubitke pretrpljene tijekom Drugoga svjetskog rata i poraća s druge strane, ${ }^{100}$ Vlaho je, u "interesu biološkog održanja" naroda, pozivao na pribiranje svih snaga u nastojanju da "nijedan pojedinac ne bude za naš narodni život izgubljen". ${ }^{101}$

97 Ž. Vlaho, Viribus unitis, str. 6.

98 Isto, str. 4.

99 Vidi: Luubomir Antić, Naše iseljeništvo u Južnoj Americi i stvaranje jugoslavenske države 1918., Školska knjiga, Zagreb, 1987.

100 Vidi: Vladimir Žerjavić, Gubici stanovništva Jugoslavije u drugom svjetskom ratu, Jugoslavensko viktimološko društvo, Zagreb, 1989.; VLADIMIR ŽERJAVIĆ, "Demografski i ratni gubici Hrvatske u Drugom svjetskom ratu i poraću", u: Časopis za suvremenu povijest, 27, Zagreb, 3/1995., str. 543-560; Josip JurČEvić, Bleiburg - Jugoslavenski poratni zločini nad Hrvatima, Dokumentacijsko informacijsko središte - Udruga ratnih veterana Hrvatski domobran - Hrvatsko društvo političkih zatvorenika, Zagreb, 2005.; MARTINA GraheK RavanČIĆ, Bleiburg i križni put 1945. - Historiografija, publicistika $i$ memoarska literatura, Hrvatski institut za povijest, Zagreb, 2009.; VLADIMIR GeIger, "Ljudski gubici Hrvatske u Drugom svjetskom ratu koje su prouzročili 'okupatori i njihovi pomagači' - Brojidbeni pokazatelji (procjene, izračuni, popisi)", u: Časopis za suvremenu povijest, 43, Zagreb, 3/2011., str. 699-749.

101 Ž. VLaho, Viribus unitis, str. 4. 
Da bi mogao odgovoriti na pitanje o mogućem utjecaju iseljenih pripadnika hrvatskoga naroda na razvoj događaja u domovini, Vlaho je iseljenički korpus razdijelio u dvije osnovne skupine: staro i novo iseljeništvo, tj. je li se radilo o osobama koje su napustile domovinu prije Drugoga svjetskog rata ili tek poslije njegova završetka. Raščlanjujući strukturu starog iseljeništva Vlaho je podjednako uzimao u obzir namjeru njegova povratka u Hrvatsku, ali i mogućnost ostan$\mathrm{ka} \mathrm{u}$ inozemstvu. Odluka iseljenika da se trajno nasele u zemljama koje su im pružile gostoprimstvo, postavljala je pitanje je li tu riječ o ljudima koji se "smatraju dijelom živog hrvatskog organizma" ili se radilo o osobama koje su "potpuno izgubile svoju hrvatsku narodnu svijest". ${ }^{102}$ Vlaho je nove iseljenike podijelio u tri skupine: a) aktivni nositelji i dužnosnici ustaškoga režima, b) bivši pripadnici partizanskoga pokreta, odnosno borbenih jedinica i c) četnici. ${ }^{103}$

Svi su se iseljenici, neovisno o tome u koju ih je skupinu Vlaho razvrstao, mogli uključiti u slanje pomoći u raznim oblicima svojim sunarodnjacima u "zarobljenoj domovini" te ih na taj način spasiti od "propadanja u siromaštini i gladi". ${ }^{104}$ To je trebao biti jedini pravi način da dokažu "iskrenost i poštene namjere" i da rade "iz potrebe političko-moralne obnove sebe i hrvatske sredine". ${ }^{105}$

Prva je dužnost iseljenih Hrvata, a "napose intelektualca", bila da "OZBILJNO SPREME SAMI SEBE ZA RAD U OSLOBODJENOJ DOMOVINI". ${ }^{106} \mathrm{U}$ tom je smislu, kao misao vodilju, Vlaho naveo sljedeće riječi: "Trebamo najprije naći sebe kao ljude, katolike i Hrvate, proniknuti se idejom i spremom za apostolat, da bismo mogli nastupati s punim uvjerenjem i autoritetom."107

102 Isto.

103 Isto.

104 Isto, str. 5-6.

105 Isto, str. 6-7. Vidi: "Pojava jedne nove revije", u: Hrvatska, Buenos Aires, 15. veljače 1949., str. 5. Riječ je o kritičkom osvrtu na mjesečnik Sloboda (Buenos Aires) koji je 1949. pokrenuo Ivo Bogdan (1907.-1971.), nakon što se politički udaljio od A. Pavelića.

106 Ž. Vlaho, Viribus unitis, str. 5.

107 Isto. Vidi: Exul, "Naša velika odgovornost", Osoba i duh, 1, Albuquerque, 5-6/1949., str. 7. Publikaciju su kao "reviju za duhovno-naučna/znanstvena pitanja" pokrenuli o. Hijacint Eterović (1913.-1981.) i Luka Brajnović (1919.2001.). Časopis je u početku izlazio u Albuquerqueu, a kasnije u Madridu. 
Da bi Hrvati mogli imati "slobodnu, samostalnu i demokratski uredjenu vlastitu državu", u čemu im u datim povijesnim okolnostima nije mogla pomoći neka politička stranka, Vlaho se okrenuo traženju saveznika: "ako smo svjesni, da bez pomoći Zapada, a napose Sjed. Američkih Država, u čije je ruke konačno prešlo vodstvo svjetske politike, ne možemo postići našega cilja", postavlja se odlučujuće pitanje - tko će predstavljati Hrvate u njihovoj borbi. ${ }^{108}$ Drugim riječima, tražila se osoba koja će "na pravom mjestu znati i umjeti ispravno i energično zastupati prava i volju hrvatskog naroda". ${ }^{109}$

Vlaho je potražio odgovor u Danici, ${ }^{110}$ glasilu hercegovačkih franjevaca u Chicagu, i u ustaškoj Hrvatskoj.

Chicaški je list, u povodu Mačekova trajnog nastanjenja u Washingtonu, ${ }^{111}$ objavio članak u kome se, između ostaloga, navodi i sljedeće: "Najvažnije je ipak to, da dr. Maček nije u Washingtonu tek kao predsjednik HSS, nego i kao predstavnik cijeloga hrvatskog naroda. Ovo ne velimo (...) jer želimo nekoga povući nekamo protiv volje, nego zato, jer je HSS posljednjih izbora ${ }^{112}$ istupala ne kao stranka, nego kao opći hrv. narodni pokret, koji se borio ne samo za soc. program, nego i za pol. slobodu i samostalnost."113

Pavelićevo je glasilo u Buenos Airesu objavilo tekst u kome se o Mačeku govorilo sljedeće: "Mi Hrvati kao nacija, u ovom času, imamo samo dvije izrazito političke vrijednosti. To su Hrv. nar. otpor ${ }^{114}$ sa

108 Ž. Vlaho, Viribus unitis, str. 7.

109 Isto.

110 Danica (1920.-1990.), vjersko-politički tjednik koji su hercegovački franjevci kupili 1945. od Ivana Krešića/Kresicha (1878.-1956.). List su od 1945. do 1951. uređivali fra Ljubo Čuvalo (1908.-1975.) i fra Kruno Pandžić (1912.1965.).

111 Maček se doselio u Washington 30. kolovoza 1947. i u njemu je ostao sve do kraja života. I. Perić, Vladko Maček, str. 285.

112 Misli se na posljednje parlamentarne izbore u Kraljevini Jugoslaviji. Vidi: Tomo JančIKović, Hrvati u izborima 11. prosinca 1938., Zagreb, 1939.

113 Ž. Vlaho, Viribus unitis, str. 7. Vidi: Dr. V. V., "Predstavnik i vođa hrv. naroda u Washingtonu", u: Danica, Chicago, 24. rujna 1947., str. 4.

114 O nastanku Hrvatskoga narodnog odpora/otpora vidi: ZDENKo RADELIĆ, Križari: gerila u Hrvatskoj 1945.-1950., Alfa d.d. - Hrvatski institut za povijest, Zagreb, 2011., str. 64-69. Istoimenu je organizaciju, nakon razlaza s A. Pavelićem, u Španjolskoj 1955. osnovao Vjekoslav Maks Luburić (1913.1969.). 
svojim borcima u šumama domovine i HSS s drom Mačekom na čelu u inozemstvu.... Prvi djeluju na terenu u domovini, a drugi bi trebali djelovati na diplomatskom području u inozemstvu. Ozbiljno diplomatski (...) u smislu istinske hrv. narodne i državne politike, mogao bi, barem zasad, djelovati na Zapadu samo dr. Maček. (...) Maček se osobno nije u ništa miješao, pa ima barem tu prednost, da mu se osobno ne može predbaciti ni s jedne strane, da je bio aktivan u korist ovih ili onih snaga, koje su bile u borbi za vrijeme ovog rata. Svatko drugi živi u iluzijama, ako misli, da isto tako može, uime hrv. naroda, djelovati diplomatski kod današnjih odlučnih diplomatskih faktora na Zapadu. Dok je politički aktivna ona generacija zapadnih političara, koja je učestvovala u ovom posljednjem svjetskom sukobu, uime $\mathrm{Hr}$ vata, može, zasad, ozbiljnije djelovati samo dr Maček."115 U nastavku članka stoji: "Onima, koji nisu i ne mogu biti pristaše dra Mačeka, ostaje mjesto u Hrvatskom Narodnom Odporu, koji djeluje na temelju neposredne volje i snage hrvatskog naroda u Domovini, da svojim uspjesima na terenu podupre diplomatski rad dra Mačeka, odnosno, da loše posljedice njegovih eventualnih diplomatskih pogrješaka sprieči i dovede do pobjede istinsku hrvatsku narodnu volju."116

Akcije koje je Hrvatski narodni odpor (HNO) vodio u domovini u prvim poslijeratnim godinama, doživjele su potpuni neuspjeh ("Akcija 10. travanj", "Operacija Gvardijan"), što je za posljedicu imalo gašenje organizacije u Buenos Airesu. ${ }^{117}$

Vlaho je, naravno, odlučno odbacivao bilo kakvu mogućnost da bi HNO kao "vrijednost" mogao stajati pokraj V. Mačeka. ${ }^{118}$

Za Vlahu nije bilo mjesta sumnji da bi se, nakon svega što je iznio, svi Hrvati "morali složiti" sa stajalištima objavljenima u Danici i Hrvatskoj i "biti sretni, da će težnju hrv. naroda za slobodom" i "vjekovno pravo na vlastitu državu, kao formu, izraz i stvaran sadržaj nacionalne individualnosti, samobitnosti i političke zrelosti dr. Vladko Maček, kao narodni predstavnik i dugogodišnji borac znati tumačiti te smjelo

115 Ž. Vlaho, Viribus unitis, str. 7-8. Vidi: "Hrvatska 'Treća snaga'", str. 3.

116 "Hrvatska 'Treća snaga'", str. 3.

117 Ž. Vlaho, Viribus unitis, str. 8; Z. Radelić, Križari, str. 143-153. Također vidi: Ivan Prusac, Tragedija Kavrana i drugova - Svjedočanstvo preživjelog, Riječki nakladni zavod d.o.o., Rijeka, 1996.; Ivan Prusac, Akcija Deseti travanj - U svjetlu svjedoka: dokumentacije, Hrvatski oslobodilački pokret, Zagreb, 1989.

118 Ž. Vlaho, Viribus unitis, str. 8. 
i spretno nastupati pred Amerikom, njenom vladom i demokratskim zapadom".119 Stoga su, nastavlja Vlaho, pozivajući se na pozdravne riječi upućene Mačeku na stranicama Danice, "oči Hrvata uprte u Te; od Tebe očekuju izbavljenje, jer si im ostao zadnje utočište". ${ }^{120}$

Znajući da će njegovo zauzimanje za Mačekovo prvenstvo u vođenju hrvatske politike pred službenim krugovima na Zapadu biti od mnogih osporavano, Vlaho je posegnuo za dodatnim argumentom koji je trebao razoružati sve one koji nisu dijelili njegovo mišljenje. Tu je ključnu ulogu trebao odigrati A. Pavelić, koji je pod "dojmom strahovite tragedije hrvatskog naroda" nakon završetka Drugoga svjetskog rata, u jednom "svijetlom momentu", izrekao isto ono mišljenje koje su Danica i Hrvatska iznosile na svojim stranicama vezano uz predmnijevanu političku ulogu V. Mačeka. Ustaški pukovnik Ante Moškov (1911.-1948.? ${ }^{121}$ navodno je, obilazeći hrvatske izbjegličke skupine u logorima po Italiji (Fermo i dr.), ${ }^{122}$ prenio i Pavelićevu poruku da "svi Hrvati sve snage moraju staviti na raspolaganje dru Mačeku, da mu ne treba nikakove smetnje praviti i da ga treba u cijelosti pomagati". ${ }^{123}$ Vlaho je, među svjedocima koji su potvrđivali autentičnost Pavelićeve poruke, naveo i ustaškog pukovnika Božidara Kavrana (1913.-1948.), koji je u tom smislu dao izjavu tijekom sudskog procesa u Zagrebu sredinom kolovoza 1948. ${ }^{124}$

Prije nego li se moglo donijeti konačnu odluku o tome smiju li se Hrvati "pouzdati u vodstvo dra Mačeka", trebalo je, nastavlja Vlaho, s "objektivnog nacionalističkog stanovišta" ispitati "kakovo stanovište on zauzima prema aktualnim, najvitalnijim problemima hrv. naroda", tj. kakvo stajalište V. Maček zauzima prema "težnji hrvatskog naroda za slobodom i nezavisnošću" te prema kralju Petru II. Karađorđeviću (1923.-1970.), Srbima i Jugoslaviji. ${ }^{125}$

119 Isto, 9. Vidi: Dr. V. V., "Predstavnik i vođa hrv. naroda u Washingtonu", str. 4.

120 Ž. Vlaho, Viribus unitis, str. 9. Vidi: "Dobro nam došao!", u: Danica, Chicago, 27. kolovoza 1947., str. 1.

121 Vidi: Ante Moškov, Pavelićevo doba, Laus, Split, 1999.

122 O izbjegličkim logorima i sudbini u njima smještenih osoba vidi: BERISLAV JANDRIĆ, "Prijepori saveznika oko zahtjeva Jugoslavije za izručenjem osumnjičenih za ratne zločine iz savezničkih izbjegličkih logora u Italiji 1945.1947.", u: Časopis za suvremenu povijest, 38, Zagreb, 2/2006., str. 457-498.

123 Ž. Vlaho, Viribus unitis, str. 9.

124 Isto.

125 Isto, str. 9-10. 
Iako je držao da nije potrebno dokazivati da je V. Maček "proti SADAŠNJOJ JUGOSLAVIJI" i njezinu komunističkom vođi Josipu Brozu Titu (1892.-1980.), jer mu to ne spočitavaju ni najljući protivnici, ${ }^{126}$ Vlaho se odlučio na navođenje nekoliko primjera iz kojih se, prema njegovu mišljenju, moglo najbolje vidjeti Mačekovo stajalište prema hrvatskoj državnoj neovisnosti.

Kao prvi primjer navedena je žalobna sjednica kluba Seljačko-demokratske koalicije održana 11. kolovoza 1928. povodom smrti Stjepana Radića nakon atentata u Narodnoj skupštini Kraljevine SHS. ${ }^{127}$ Tom je prigodom V. Maček izrekao i sljedeće riječi: "Iz prava hrvatskog seljačkog naroda, da sam sobom vlada, slijedi logičkom nuždom i pravo toga naroda na svoju slobodnu državu Hrvatsku (...)."128

Maček je, u vrijeme Banovine Hrvatske, ${ }^{129}$ preko svoga izaslanika Gjure Maršića (1894.-1970.), tijekom audijencije hrvatskoga izaslanstva 14. studenoga 1939. u Vatikanu, koje je predvodio hrvatski katolički episkopat na čelu s nadbiskupom Stepincem, ${ }^{130}$ predao papi Piju XII. svečano pismo (adresu), u kojem je stajalo kako je hrvatski narod više od tisuću godina "ostao čvrsto i nepomično na braniku svoje zemlje kao samostalne i nezavisne političke jedinice". ${ }^{131}$

Našavši se nakon završetka Drugoga svjetskog rata u izbjeglištvu, Maček je svojim sunarodnjacima, koji su već od prije živjeli izvan domovine, morao dati nedvosmislen odgovor o svom odnosu prema hrvatskoj državnoj samostalnosti. Savez hrvatskih svećenika u SAD-

126 Mačekovo političko djelovanje u emigraciji napadano je iz ustaških redova. Vidi: Danijel Crljen, Otvoreno pismo dru Vladimiru Mačeku predsjedniku Hrvatske seljačke stranke, Nakladnik "Vratna Gora", Zagreb, 1999. Brošura je izvorno objavljena 1948. u Parizu.

127 O atentatu na S. Radića i zastupnike HSS-a vidi: Zvonimir KulundžIć, Atentat na Stjepana Radića, Novinsko izdavačka kuća "Stvarnost", Zagreb, 1967.

128 Ž. Vlaho, Viribus unitis, str. 10. Vidi: "Žalobna sjednica kluba SDK", Narodni val, Zagreb, 12. kolovoza 1928., str. 3.

129 Vidi: Ljubo Boban, Sporazum Cvetković - Maček, Institut društvenih nauka, Odeljenje za istorijske nauke, Beograd, 1965.

130 Tom je prilikom, u povodu 1300 godišnjice prvih veza Hrvata sa Sv. Stolicom, u adresi episkopata zamoljeno papu Pija XII. da bl. Nikolu Tavelića (o. 1340.-1391.) proglasi svecem Katoličke crkve. "Hrvati kod sv. Oca Pija XII.", u: Katolički list, Zagreb, 16. studenoga 1939., str. 557. Do kanonizacije je došlo tek 1970. godine.

131 Ž. Vlaho, Viribus unitis, str. 10. Vidi: "Hrvati kod sv. Oca Pija XII.", str. 558. 
u i Kanadi, ${ }^{132}$ sa sedmoga godišnjeg sastanka, održanog 19. listopada 1948. u Garyju, savezna država Indiana, uputio je Mačeku pismo u kojem ga je pozdravio kao "predstavnika hrvatskoga naroda u borbi za nacionalnu i suverenu hrvatsku državu", ali ga je ujedno zamolio da "u pitanju osnivanja samostalne i suverene hrvatske države" dade "autoritativnu izjavu".133 Odazvavši se pozivu Maček je izjavio: "Već od godine 1918, dakle trideset godina u borbi sam za samoodredjenje hrvatskoga naroda, koje se samoodredjenje sastoji u tome, da i hrvatski narod kao i ostali narodi ima pravo na svoju suverenu državu. Tu borbu vodim i danas."134

Polemizirajući s Adamom Pribićevićem (1880-1957.), članom Srpskoga nacionalnog odbora, ${ }^{135}$ Maček, prema Vlahinu mišljenju, "jasno izražava svoje stanovište o Srbima u hrvatskim zemljama, (...) o cjelovitosti svih hrvatskih pokrajina i o slobodnoj i samostalnoj Hrvatskoj", tako da mu nijedan "ultranacionalista ne može prigovoriti". ${ }^{136} \mathrm{Na}$ Pribićevićevo hipotetičko pitanje o mogućem osnutku neke buduće konfederacije na prostoru aktualne jugoslavenske države, Maček je odgovorio sljedeće: "pitanje hoće li narodi današnje Jugoslavije i nakon što se oslobode od komunističkog jarma ostati u (...) nekoj labavoj konfederaciji ili ne, a naročito, hoće li ostati u takvoj zajednici Hrvati, ovisi uz druge okolnosti, hoće li Hrvati moći sačuvati suverenitet Hrvatskog Naroda i svoje kroz vijekove gažene, kroz vijekove trgane i vijekove pokoravane Hrvatske". ${ }^{137}$

132 Vidi: ČAstimir MajıĆ, "Savez hrvatskih svećenika u SAD i Kanadi", u: Kršni zavičaj, 34 (32), Ljubuški, 2001., str. 97-114.

133 Ž. Vlaho, Viribus unitis, str. 10-11. Vidi: "Pismo hrvatskog svećenstva u Sjevernoj Americi dru Vlatku Mačeku", u: Glas sv. Antuna, Buenos Aires, siječanj 1949., str. 5.

134 Isto, str. 11. Vidi: "Odgovor dra Vlatka Mačeka hrvatskom svećenstvu", u: Glas sv. Antuna, Buenos Aires, siječanj 1949., str. 5. Sličnu je izjavu Maček dao i u svojoj božićnoj poruci 1948. godine: "Hrv. selj. stranka u svojoj borbi za slobodnu Hrvatsku Državu često je naglašavala, a naglašava i danas, da ne mogu Hrvati biti slobodni bez slobodne Hrvatske". Nav. prema: Ž. VLAHO, Viribus unitis, str. 11.

135 Srpski nacionalni odbor osnovao je 1947. Konstantin Fotić (1891.-1959.) u New Yorku.

136 Ž. VLaho, Viribus unitis, str. 11.

137 Vlatкo MačEk, "Samostalna Hrvatska i Srbi", u: Američki hrvatski glasnik, Chicago - Calumet - New York, 16. ožujka 1949., str. 1. 
U uvodniku prvoga broja novopokrenutog lista Hrvatska riječ, glasilu "hrvatskih radnika u slobodnoj Europi", iza kojeg su stajali pristaše HSS-a u Belgiji, ${ }^{138}$ Maček je napisao: "Težnju Hrvata za svojom suverenom hrvatskom državom, mora razumjeti svatko tko zna, da smo mi Hrvati već pred više od tisuću godina imali svoju suverenu državu, ali smo uslijed neumoljive sudbine gubili komad po komad svog teritorija dok nismo od godine 1918. pa dalje spali na to, da nam se počne poricati ne samo pravo, na našu državnost, nego čak i pravo da postojimo kao posebna narodna individualnost - kao hrvatski narod."139 Ipak, za Mačeka nije bila prihvatljiva bilo kakva državna tvorevina: "država je samo sredstvo koje ima zaštićivati i čuvati ljudska prava. To i samo to je ispravno shvaćanje slobodne narodne države. Jer što će mi država zvala se ona 'nezavisnom' ili 'republikom', vijale se u njoj na metre dugačke hrvatske trobojnice bilo čiste, bilo sa prikrpanim 'U' ili crvenom zvijezdom, ako mi u toj državi nisu osigurana najelementarnija ljudska prava (...)". ${ }^{140}$

Iako je ustvrdio da bi mogao "nizati" brojne Mačekove izjave u prilog suverene hrvatske države, Vlaho se zadržao na konstataciji da je izbor citata namjerno ograničio "uglavnom na one, koje je registrirala" i buenosaireška Hrvatska. To je učinio stoga da mu "nitko ni s njihove (ustaške) strane ne može prigovoriti njihovo postojanje i autentičnost". ${ }^{141}$

Iz svega što je naveo, Vlaho je izvukao dalekosežan zaključak da V. Maček "ne će srpskoga kralja Petra", odnosno da "hoće, želi, traži i bori se za slobodu hrv. naroda u njegovoj vlastitoj, slobodnoj, suverenoj državi Hrvatskoj, u svim njezinim povjesnim i etničkim granicama; da hrv. narod ima svoj novac u svom džepu, svoga hrv. vojnika sa vlastitom hrv. puškom na svom ramenu, na svojim granicama i svoje vlastite diplomatske predstavnike kod drugih slobodnih naroda". ${ }^{142}$

Unatoč Vlahinu naglašavanju Mačekove državotvornosti, bilo je razvidno da se iz netransparentnih izjava i političkih akcija vođe HSS-a nije moglo nedvosmisleno zaključiti da on odlučno odbacuje svaki

138 Vidi: "Nov hrvatski list u Belgiji", u: Glas sv. Antuna, Buenos Aires, lipanj 1949., str. 7.

139 Ž. Vlaho, Viribus unitis, str. 11. Vidi: Vladko Maček, "Smisao države", u: Hrvatska riječ, Lueven, travanj 1949., str. 1.

140 V. MAČEK, "Smisao države", str. 1.

141 Ž. Vlaho, Viribus unitis, str. 11.

142 Isto. 
oblik državnog povezivanja Hrvata s drugim narodima, prvenstveno onima koji su živjeli unutar granica Jugoslavije.

Maček je nakon odlaska u emigraciju vodio više pregovora s predstavnicima srpskih političkih organizacija o prihvaćanju zajedničke političke platforme u svrhu mogućeg stvaranja neke jugoslavenske državne zajednice. ${ }^{143}$ Svoje je stajalište najbolje obrazložio u pismu Vlahi A. Raiću (1895.-1972.): "Ja sam toliko oprezan, da se cijelo vrijeme boravka u emigraciji nisam nikada izjasnio ni za održanje ni za raspad Jugoslavije. Za ovo potonje ne ću se izjasniti, jer ne vidim ni maglovitih kontura, što bi od srušene Jugoslavije pripalo Srbima, što Madjarima, što Talijanima i što bi konačno ostalo nama."144 Za Mačeka je tada u obzir dolazila i mogućnost stvaranja južnoslavenske ili pak neke srednjoeuropske konfederacije, u koju bi bila uključena i hrvatska država. ${ }^{145}$

Iako je držao, zanemarujući pritom ukupno Mačekovo političko djelovanje, kako bi već samo na osnovi javno obznanjenih izjava "nacionalisti" okupljeni oko listova Hrvatska i Danica morali s "apsolutnim pouzdanjem prihvatiti vodstvo" predsjednika HSS-a kao jedinoga političkog predstavnika Hrvata, Vlaho se ipak odlučio za provjeru njegove vjerodostojnosti i s - "katoličkog stanovišta". ${ }^{146}$

Da bi mogao govoriti o Mačeku kao katoliku, Vlaho je najodlučnije odbacio tvrdnju da je vjera privatna stvar te da je "najveća nesreća za hrv. narod klerikalizam", odnosno kako su ga "nacisti u borbi protiv kat. Crkve nazivali 'političkim katolicizmom"'. ${ }^{147}$ Jer, nastavlja Vlaho, "Crkva je uvijek strogo osudjivala sve one, koji bi htjeli da upotrebljuju svoj crkveni položaj ili vjerski ugled u čisto pol. pitanjima ponizujući vjeru na stepen pol. instrumenta". ${ }^{148}$ Svoju je tvrdnju

143 Jere Jareb, Pola stoljeća hrvatske politike - Povodom Mačekove autobiografije, Knjižnica Hrvatske revije, Buenos Aires, 1960., str. 131.

144 Nav. prema: Isto. Vidi: Bogdan RadicA, "Vladko Maček i njegova pisma - Povijest jedne suradnje"; Dinko Šuljak, "Da li bi Maček prihvatio i treću Jugoslaviju?", u: Vinko Nikolić (ur.), Hrvatska revija. Jubilarni zbornik 1951-1975, Knjižnica Hrvatske revije, München - Barcelona, 1976., str. 414$463 ; 464-478$.

145 J. JAREB, Pola stoljeća hrvatske politike, str. 131.

146 Ž. VLAHO, Viribus unitis, str. 12.

147 Isto.

148 Isto. 
potkrijepio navodima iz papinskih okružnica ("Pergrata nobis"149 $\mathrm{i}$ "Mit brennender Sorge"). ${ }^{150}$ Vlaho već na temelju vlastitog iskustva nije dvojio da je bavljenje politikom "DUŽNOST $i$ moralna $i$ socijalna $i$ vjerska" koju "svaki pravi kršćanin mora prihvatiti i vjerno izvršavati". ${ }^{151}$ Sudjelovanjem u političkom životu katolici, ali i ostali "pravi vjernici", sprečavaju da "vlast u državi ne preuzmu ideologije $i$ pol. stranke koje su neprijatelji Boga, pa po tom i države i čovjeka, i koje su ozbiljna opasnost, da u prah pretvore i unište najveće narodne svetinje, da unište vjeru, da unište život i slobodu, da unište kršć. brak i obitelj, da unište kršć. školu, da unište i zemaljsku $i$ vječnu sreću milijuna ljudi". ${ }^{152}$ Iz navedenih je tvrdnji bilo "lako zaključiti" kome hrvatski narod može povjeriti svoju sudbinu i "kakve kvalifikacije treba da ima i onaj, koji hoće da bude ili kojega narod odabire za svoga vodju". ${ }^{153}$ Vlaho nije dvojio da je jedina osoba iz hrvatske političke emigracije koja je imala sve tražene kvalitete bio V. Maček.

Prvi svjedok koga je Vlaho pozvao da govori o Mačekovim vjerskim uvjerenjima bio je vrhbosanski nadbiskup Ivan Ev. Šarić (1871.-1960.). Prilikom zasjedanja biskupske konferencije u Zagrebu, krajem listopada 1939., Šarić je u nadbiskupskom dvoru primio V. Mačeka, tadašnjeg potpredsjednika jugoslavenske vlade. ${ }^{154}$ Nadbiskup je nakon sastanka izjavio sljedeće: "sastao sam se prvi put s vodjom hrv. naroda drom Vlatkom Mačekom... Upravo sam se divio mudrosti i jakosti duha dra Mačeka; prošli smo u razgovoru naša važnija pitanja. Kad smo bili kod konkordata i Sv. Stolice, ${ }^{155}$ izgovorio mi je dr Maček ove značajne riječi: 'Ne samo kao katolik, već i kao državnik moram biti uz Sv. Stolicu, koja je danas upravo na visini.' Kad sam se

149 Riječ je o okružnici pape Lava XIII. (1878.-1903.) objavljenoj 14. rujna 1886. pod naslovom "O Crkvi u Portugalu".

150 Ž. Vlaho, Viribus unitis, str. 12.

151 Isto, str. 13.

152 Isto.

153 Isto.

154 "Dr. Maček kod preuzv. g. Šarića", u: Hrvatska straža, Zagreb, 28. listopada 1939., str. 1.

155 Vidi: Ivan MužIć, Katolička crkva u Kraljevini Jugoslaviji - Politički i pravni aspekti konkordata između Svete Stolice i Kraljevine Jugoslavije, Crkva u svijetu, Split, 1978. 
oprostio s njim, rekao mi je 'Bog s Vama'. Doista, g. dr Maček, vodja hrv. naroda, u svemu svome radu misli na Boga". ${ }^{156}$

U već ranije spomenutom svečanom pismu, uručenom papi Piju XII., pisanom latinskim jezikom na pergamentu te ukrašenom hrvatskim grbom i potpisanom od V. Mačeka kao "vodje hrvatskog naroda" ("dux populi croatici"), stajalo je, između ostaloga, da mu je dužnost posebno naglasiti "PRIVRŽENOST HRVATSKOGA NARODA RIMOKATOLIČKOJ CRKVI KAO NOSITELJICI VJEČNE ISTINE, SOCIJALNE PRAVDE I MEDJUNARODNE SOLIDARNOSTI U SVIJETU". ${ }^{157} \mathrm{Za}$ Vlahu je to bila "FORMALNA ISPOVIJEST VJERE u Kristovo Božanstvo i u vrhunaravnu misiju kat. Crkve" pred Kristovim Namjesnikom na zemlji. ${ }^{158}$

Izjave nadbiskupa Stepinca, najvišega crkvenog autoriteta u Hrvatskoj, tijekom sudskoga procesa koji se vodio protiv njega 1946. u Zagrebu, također su trebale svjedočiti o Mačekovoj političkoj podobnosti kao vođi hrvatskoga naroda. ${ }^{159}$

Mačekovo se duboko vjersko uvjerenje prepoznavalo i u njegovim pjesmama nadahnutima vjerskom tematikom i u božićnim porukama pristašama. ${ }^{160}$

Čuvši neke Mačekove javne izjave, nadbiskup je Stepninac bio sumnjičav prema njegovu poznavanju katoličkih dogmi: "Po svemu vidim, da je Dr. Maček slabo potkovan u istinama vjere katoličke (...)."161

Zanimljivo je da je Vlaho, iako je s tim bio dobro upoznat, ignorirao, barem javno, činjenicu da predmnijevani vođa hrvatskoga na-

156 Nav. prema: Ž. Vlaho, Viribus unitis, str. 14.

157 Isto. Vidi: "Papa Pio XII. hrvatskom narodu", u: Hrvatska straža, Zagreb, 15. studenoga 1939., str. 2.

158 Ž. VLAHO, Viribus unitis, str. 14.

159 Ž. Vlaho, str. 25. Vidi: Milan Stanić (ur.), Suđenje Lisaku, Stepincu, Šaliću i družini, ustaško-križarskim zločincima i njihovim pomagačima, Izdavač Milan Stanić, Zagreb, 1946., str. 223, 285.

160 Ž. Vlaho, Viribus unitis, str. 15. Vidi: "Vođa hrvatskog naroda dr Vladko Maček za Svetište", u: Vjesnik Svetišta Kraljice Hrvata Majke Božje Lurdske, 2, Zagreb, 1-5/1940., str. 8; VladKo MAČEK, "Božić", u: Hrvatski katolički glasnik, 4, Chicago, 12/1945., [str. 406].

161 Nav. prema: "Alojzije Stepinac: nepoznati Dnevnik", u: Danas, Zagreb, 3. listopada 1989., str. 65. 
roda nije svoj drugi brak sklopio u Katoličkoj crkvi. ${ }^{162}$ Ipak, Maček je, srećom po Vlahu, svoj bračni status uredio u skladu s rimokatoličkim crkvenim propisima prije nego što je knjižica Viribus unitis bila objavljena. ${ }^{163}$ Prešućivanje te, $s$ katoličke točke gledišta, neugodne istine bilo je u funkciji građenja nepomućene slike o Mačeku kao idealnom nacionalnom i katoličkom borcu za hrvatsku suverenost.

Unatoč svemu, Vlahin je zaključak bio očekivan: "KATOLICI mogu imati PUNO POVJERENJE u dra. VL. MAČEKA KAO VODJU HRV. NARODA, jer je njegov rad, napose njegovo nastojanje, težnje i borba za slobodu hrv. naroda OSTALA DO DANA DANAŠNJEG U SKLADU SA OSNOVNIM NARODNIM IDEALIMA i moralnoetičkim vjerskim pogledima hrv. naroda (...)". ${ }^{164}$ Priznavanje Mačeka neprijepornim vođom hrvatskog naroda isključivalo je, barem privremeno, potrebu osnivanja političke stranke jer je "svaka takva akcija protuhrvatska $i$ štetna za stizanje cilju", tj. uspostavu slobodne hrvatske države. ${ }^{165}$

Privremeno odustajanje od organiziranja bilo kakve političke stranke trebalo je potrajati "sve dotle", dok se ne postigne "narodno oslobodjenje i slobodnu i samostalnu demokratsku državu Hrvatsku". 166 U uvjetima postojanja samostalne države došlo bi na red "unutarnje uredjenje i rješavanje kulturnih i socijalnih problema" te osnivanje političkih stranaka. Prema Vlahinu mišljenju "HSS može i u oslobodjenoj domovini da bude većinska stranka hrv. naroda i da predstavlja i katolički elemenat". ${ }^{167}$ To naravno nije značilo da će hrvatski

162 Nadbiskup Stepinac je u povodu Mačekova građanskog braka zapisao: "To bi dakle imao biti 'vođa' hrvatskog naroda, koji je pljunuo u zakon Božji i dok mu je zakonita (prva) žena živa već po drugi put vjenča se civilno. Mislim da takvi ljudi neće spasiti hrvatskog naroda". Nav. prema: "Alojzije Stepinac: nepoznati Dnevnik", u: Danas, Zagreb, 19. rujna 1989., str. 63-64.

$163 \mathrm{BiH}$, AHFP, MO, kut. 4, sv. 4, mp. 3, f. 414, Ž. Vlaho D. Mandiću; pismo je datirano u Buenos Airesu, 6. listopada 1951. Stepinčeve riječi, izrečene još prije rata, pokazale su se, barem kada se radilo o Mačekovu građanskom braku, proročanskima: "No nadamo se, da će Bog dragi ipak i ovo zlo izvesti na dobro, i da će Dr. Maček ovo sve popraviti, pa u skladu s katoličkom crkvom raditi na dobrobit hrv. naroda". Nav. prema: "Alojzije Stepinac: nepoznati Dnevnik", u: Danas, Zagreb, 19. rujna 1989., str. 64.

164 Ž. Vlaho, Viribus unitis, 25.

165 Isto, str. 25-26.

166 Isto, str. 26.

167 Isto. 
katolici prihvatiti ideologiju HSS-a kako ju je formulirao Rudolf Her$\mathrm{ceg}^{168} \mathrm{u}$ svojim radovima, pogotovo kad je riječ o vjerskom nauku Crkve. ${ }^{169}$ Vlaho je, ipak, izrazio duboko uvjerenje, da će vodstvo HSS-a znati pridobiti za suradnju "katoličke intelektualce" time što će svoj "program i rad" uskladiti s "osnovnim narodnim idealima" i njegovim "moralno-etičkim i vjerskim pogledima". ${ }^{170}$ Katolički episkopat na čelu s "biskupima-mučenicima" Stepincem i Čulom ${ }^{171}$ trebao je biti jamstvo da će se stranačko-politički život u Hrvatskoj doista odvijati $\mathrm{u}$ željenom smjeru. ${ }^{172}$ Takav razvoj političkih odnosa u "samostalnoj Hrvatskoj" isključivao je potrebu osnivanja - "kat. pol. stranke". ${ }^{173}$

Za Vlahu je bilo važno izreći sud i o suradnicima ("okolini") V. Mačeka. Prema njegovu mišljenju, Maček nije imao velik izbor u biranju suradnika te se morao osloniti na "one i onakve, kakvi su se našli u emigraciji i u njegovoj blizini". ${ }^{174}$ Nekolicina politički ili moralno nedostojnih pojedinaca koji bi se eventualno našli među Mačekovim suradnicima nije, prema Vlahinu shvaćanju, mogla "utjecati na dra Mačeka" i njegova politička stajališta nego su prvenstveno škodili interesima HSS-a. ${ }^{175}$ Zanimljivo je da Vlaho u Mačekovu "okolinu" nije ubrajao J. Krnjevića, ${ }^{176}$ za koga je ustvrdio da je riječ o osobi u koju hrvatski narod i njegov vođa mogu "bez ikakova straha" imati povjerenje. ${ }^{177}$

168 R. Herceg (1887.-1951.), član Glavnog odbora HSS-a.

169 Ž. VLAHO, Viribus unitis, str. 26.

170 Isto.

171 Biskup Čule je na montiranom procesu 1948. osuđen na 11 godina i 6 mjeseci zatvora. Na uvjetnu je slobodu pušten 1955.

172 Ž. VLAHo, Viribus unitis, str. 26.

173 Isto, str. 26-27.

174 Isto, str. 29.

175 Isto.

176 Vidi: Neda Prpić, Dr. Juraj Krnjević - Tri emigracije - Razgovori - pisma - prilozi, I., Udruga za promicanje hrvatske političke povijesti "Neda PrpićGamiršek", Zagreb, 2004. Iz objavljene korespondencije vidljivo je da su Vlaho i Krnjević bili u bližim prijateljskim odnosima. Isto, str. 149.

177 Ž. VLAHO, Viribus unitis, str. 28. 
Raščlanivši hrvatsku emigrantsku političku pozornicu, Vlaho je bio uvjeren da je dokazao kako je V. Maček bio jedina politička osoba koja je svojom vjerodostojnošću i međunarodnim ugledom jamčila ostvarenje suverene i demokratske hrvatske države. Svi hrvatski politički čimbenici, ukoliko su išli za istim ciljem, morali su poduprijeti Mačeka u njegovu radu.

Vlahine misli iznesene u knjižici Viribus unitis nisu naišle na razumijevanje širega kruga hrvatskih političkih emigranata raštrkanih diljem svijeta. 


\section{Viribus Unitis - Croatian Political Emigration under the Critical View of Zarko Vlaho}

\section{Summary}

At the beginning of the $20^{\text {th }}$ century, the Croatian Catholic Movement was founded in the Triune Kingdom of Croatia, Slavonia and Dalmatia, as well as in Bosnia and Herzegovina, the countries within the Austro-Hungarian Monarchy. In 1912/1913 the Croatian Catholic Seniority was established, the leading organization of the entire Catholic movement in Croatian countries. Part of the Seniors (so called "nationals") opted for Yugoslav ideology and actively engaged in the demolition of the Monarchy and the creation of the Kingdom of Serbs, Croats and Slovenes / Yugoslavia during the First World War. After the establishment of a new state, Seniority for Herzegovina (1919) was organized in Mostar, under the leadership of Fr. Dominik Mandic (senior national). One of the most important members of the Seniority was Zarko Vlaho (1895-1960), Mandic's friend and associate. Seniors sought to realize their political ideas through the Croatian People's Party. In the period of multi-party parliamentary democracy, their members were the most controversial opponents of Stjepan Radic and his Croatian Peasant Party.

After the end of World War II, Vlaho, after shorter detention in Italy, joined his family in Argentina (1947). Reflecting on the Croatian political emigration, in his book Viribus Unitis (1950), he fiercely criticized the attempts of former Ustashi movement members to organize their parties. Putting under his Catholic scalpel Vladko Macek, the president of HSS, Vlaho took up the task of gathering all the Croatian emigrant forces around him, holding that Macek was the only person who could, through his political authority and Catholic worldview and international reputation, lead to the creation of an independent Croatian state. In his endeavor, Vlaho deliberately neglected the facts that did not support his claims (Macek's non-transparent political statements, his civil marriage etc.). 
Vlaho's thoughts did not echo among a wider circle of political emigrants scattered from Europe and Africa to North and South America.

Keywords: Zarko Vlaho; Dominik Mandic; Vladko Macek; Aloysius Stepinac; Viribus Unitis; Croatia; Catholic church; Croatian Catholic Movement; Ustashi movement; totalitarianism; political emigration; political parties. 